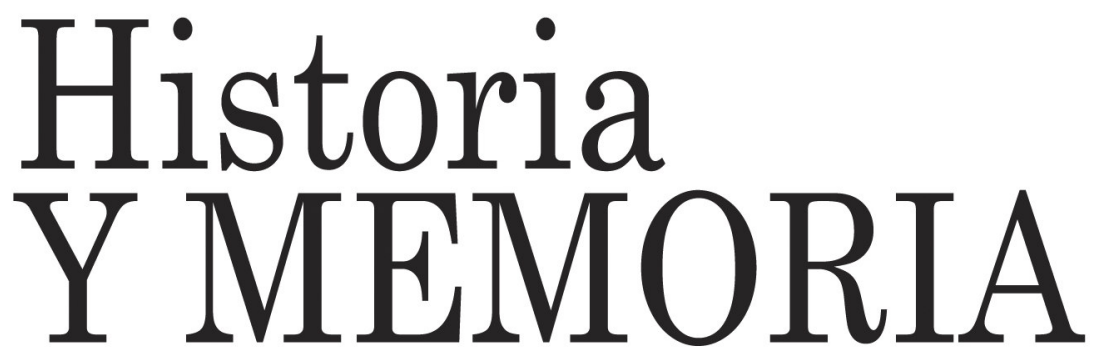

ISSN: 2027-5137

Julio - Diciembre, Año 2013 - Tunja, Colombia

La memoria cultural en Warburg y las limitaciones de la construcción de la memoria nacional en Colombia: el regeneracionismo y el pasado precolombino

Javier Vilaltella

Páginas: 113 - 166

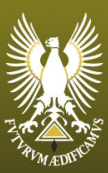




\title{
La memoria cultural en Warburg y las limitaciones de la construcción de la memoria nacional en Colombia: el regeneracionismo y el pasado precolombino
}

\author{
Javier Vilaltella ${ }^{1}$ \\ Universidad de Munich-Alemania
}

Recepción: 16/08/2013

Evaluación: 18/08/2013

Aprobación: 11/10/2013

Artículo de Investigación e Innovación

\section{Resumen}

Los temas relacionados con la memoria y la historia ocupan un espacio creciente en las teorías culturales. En este trabajo se explora con carácter prospectivo el potencial de las ideas de Aby Warburg para resituar algunos aspectos del pasado precolombino en lo que respecta a sus imágenes. Warburg ofrece un análisis basado en consideraciones antropológicas y no estilísticas, al mismo tiempo vincula imagen y memoria, sobre todo con su concepto de "pervivencia". Se muestran las limitaciones del discurso histórico colombiano creado por la Regeneración, el análisis se centra en la imagen de cabecera del Papel Periódico Ilustrado, una imagen muy elaborada y que resume su pensamiento histórico en el

\footnotetext{
${ }^{1}$ Doctor en Historia del Arte, Universidad de Munich. Estudios en Filosofía y Letras, Universidad Autónoma de Madrid. Profesor de Estudios Culturales, Universidad de Munich. Javier.Vilaltella@romanistik.uni-muenchen.de
} 
cual no hay cabida para el pasado anterior a la llegada de los españoles. Se muestran algunos modelos de "pervivencia" de las imágenes de ese pasado y se plantea de una manera general la cuestión de la liberación de su potencial, más allá de su presencia museística, las tensiones entre archivo y memoria, y la necesidad de rescatar "los restos" y "fragmentos" como formas de "pervivencia".

Palabras clave: Colombia, Aby Warburg, Regeneración, memoria visual.

\title{
Cultural memory in Warburg and the limitations of the construction of national memory in Colombia: Regenerationism and the Pre-Columbian past
}

\begin{abstract}
Topics associated with memory and history occupy a growing space in cultural theories. This prospective study will explore the potential of the ideas of Aby Warburg in resituating aspects of Pre-Columbian past, particularly regarding its images. Warburg offers an analysis based on anthropological considerations, rather than stylistic ones; linking together image and memory, especially through the concept of "survival". This study shows the limitations of Colombian historical discourse, created by Regenerationism. The analysis focuses on the central image of illustrated newspaper: this is a very elaborate image that summarizesa type of historical thought in which there is no space for a past previous to the arrival of the Spanish. Consequently, we show some models of "survival" of the images of this past, and propose the issue of liberating their potential beyond presence in the
\end{abstract}


museum, the tensions between archive and memory, and the need to rescue "remains" and "fragments" as forms of "survival".

Key words: Colombia, Aby Warburg, Regeneration, visual memory.

\section{La mémoire culturelle chez Warburg et les déficits de la construction de la mémoire nationale en Colombie: la Régénération et le passée précolombien}

\section{Résumé}

Les sujets concernant la mémoire et l'histoire occupent un espace croissant dans les théories culturelles. Ici nous voulons explorer de manière prospective le potentiel des idées d'Aby Warburg pour resituer quelques aspects du passé précolombien, au sujet de ses images. Warburg offre une analyse basée sur des considérations anthropologiques et non pas stylistiques, en même temps qu'il lie l'image et la mémoire, particulièrement à partir de son concept de "survivance". Le texte, qui montre les déficits du discours historique créé par les leaders de la Régénération, part de l'analyse d'une image très élaborée paru dans le Papel periódico ilustrado, laquelle résume la pensée historique de ces dirigeants, selon laquelle il n'y a pas de place pour le passé antérieur à l'arrivée des Espagnols. Le texte montre également quelques types de "survivance" des images de ce passé et se pose la question de la libération de sa potentialité, au-de là de sa présence dans les musées, les tensions entre les archives et la mémoire, et la nécessité de récupérer des "restes" et des "fragments" comme formes de "survivance".

Mots clés: Colombie, Aby Warburg, Régénération, mémoire visuelle. 


\section{La memoria colectiva como problema: Consideraciones generales y las ideas de Aby Warburg}

Los problemas relacionados con la memoria colectiva han cobrado especial virulencia en la segunda mitad del siglo XX por la enormidad de los procesos de genocidio, en especial contra los judíos, pero tambien algunos anteriores de no menor gravedad como fue el perpetrado a principios de siglo contra los armenios. Esto ha provocado la necesidad de crear potentes artefactos de memoria, para recordar y sobre todo evitar que en el futuro puedan repetirse. Esta visión de la memoria colectiva está muy vinculada a los procesos de violencia y sus secuelas traumáticas en la memoria. ${ }^{2}$

En Latinomérica después de la acción represiva de las dictaduras militares en varios países en los años 60 y 70 con sus secuelas de varios miles de ciudadanos asesinados y desaparecidos, ha hecho surgir también el problema de la memoria colectiva. La reconstrucción de ese pasado, que todavía es negado o minimizado por algunos sectores de la sociedad, está en pleno proceso. Hay que destacar la insistencia del cine argentino en sacar a la luz los aspectos más sombríos de la actuación de los dictadores militares. ${ }^{3}$

En Chile a su vez, la Revista de Crítica Cultural, a lo largo de todos los años de su publicación, realizó una muy intensa reflexión sobre las consecuencias derivadas de la violencia en su país pero válidas para el resto de

\footnotetext{
${ }^{2}$ Festschrift für Hans Keilson, "Geschichte und Trauma”, Frankfurt, 1991; Kongress, Tel-Aviv, Holocaust und Trauma, Göttingen 2011,

3 Entre los numerosos films sobre el tema cabe destacar "Historia oficial", Dir. José Luis Puenzo y Garage Olimpo, Dir. Marco Bechis, 1999.
} 
países latinoamericanos. ${ }^{4}$ Una nueva dimensión de este proceso de recuperación de la memoria la constituyen los "Museos de la Memoria histórica", creados en varios países. En estos casos con la intervención de las instancias oficiales, un proceso todavía reciente para poder realizar un balance adecuado.

En relación con Colombia, por desgracia, los procesos de violencia todavía no pueden considerarse como algo que pertenezca al pasado. Pero aún así hay que destacar que desde el mundo del arte se han creado potentes obras, que pueden constituir un elemento importante para procesos posteriores de reconstrucción de la memoria más amplios. ${ }^{5}$

De todas maneras los temas relacionados con la memoria colectiva no se limitan ni surgen con la necesidad de recordar los procesos traumáticos de la historia. En realidad surgen en la primera mitad del siglo XX desde la reflexión sociológica en especial con los trabajos de Halbwachs en su estudio de los mecanismos de estructuración y cohesión social, mostrando que la memoria colectiva es un elemento fundamental. ${ }^{6}$ Los diversos constituyentes de la memoria colectiva se van

${ }^{4}$ La Revista de Crítica Cultural se publicó en Chile de 1990 a 2008, bajo la dirección de Nelly Richard. Existe una selección de textos en Richard, Nelly "Antología", Revista de Crítica Cultural, Ed. Arcis, Santiago de Chile, 2009)

5 Entre otros cabe destacar la obra de Doris Salcedo, Jose Alejandro Restrepo, Echavarría y Oscar Muñoz.

${ }^{6}$ Entre otros Maurice Halbwachs, Les cadres sociaux de la mémoire y La mémoire collective (Presses universitaires de France: 1939). Otros títulos fundamentales sobre la memoria cultural y la memoria colectiva, Nora, Pierre "Lieux de memoire" 7 vols; Assmann, Jan "Das kulturelle Gedächtnis, Schrift, Erinnerung und politische Identität in früheren Hochkulturen" (París: 1986-1992); Assmann, Adelaida, "Geschichte und Gedächtnis, von der individuellen Erfahrung zur öffentlichen Inszenierung" (München:2007). 
sedimentando, entre otros, en la construcción de la visión del propio pasado en la historia. Dentro de este contexto más amplio de cuestiones, es donde tienen su relevancia los planteamientos de Aby Warburg (1866-29). Él percibió que dentro de la construcción de la memoria colectiva las imágenes jugaban un papel central. Su experiencia no fue, sin embargo, la de la ruptura o la del olvido, sino fue mas bien la de constatar la continuidad de motivos y fórmulas que habían pervivido a lo largo de los siglos en el mundo europeo. Es probable que la experiencia de la Primera Guerra Mundial le llevara a pensar que esa herencia surgida en el mundo grecoromano y conservada a lo largo de los siglos, estuviera seriamente amenazada como consecuencia de las secuelas de la guerra.

Elintento de reducir el pensamiento de Aby Warburg a una serie de conceptos básicos e instrumentalizarlos en un contexto cultural tan alejado del que fue su campo de estudio toda su vida, supone asumir muchos riesgos. En primer lugar, se sacrifica su amor al detalle con el peligro de producir una gran simplificación de su pensamiento. Su método de trabajo consistió precisamente en realizar estudios detalladísimos del contexto cultural en el que surgieron las obras fundamentalmente del Renacimiento. Estos estudios no le llevaron a escribir obras programáticas de carácter general donde se resumieran las ideas básicas que guiaban su pensamiento. Mas bien, sus ideas se derivan de la exposición del papel que jugaban las imágenes dentro de esos contextos. ${ }^{7}$

Por otro lado, su obra y su equipo de investigadores, como efectos de la persecución nazi, tuvo que emigrar a Londres en el año de 1933. En los años posteriores

${ }^{7}$ Como ejemplo de su método de trabajo ver: En edición española Warburg, Aby "Sandro Botticelli" (Madrid: Casimiro Libros, 2010). 
tuvo una recepción muy deficiente circulando casi exclusivamente desde la perspectiva iconográfica creada por Panofsky. Ello dejaba fuera los aspectos más innovadores de su pensamiento. En la postguerra, la Universidad de Hamburgo asumió la tarea de retomar la obra de Warbug y darla a conocer en su totalidad. En el año 2010 se produce finalmente una edición de sus obras completas en alemán. ${ }^{8}$

En el marco del mundo hispánico hay que destacar la exposición realizada en el MNCARS, el museo Reina Sofía de Madrid en el año 2011. Esta exposición tenía como título Atlas, como llevar el mundo a sus espaldas comisariada por Georges Didi-Huberman. El catálogo, aparte de la información sobre la exposición, contiene uno de los textos más sistemáticos en torno al concepto de Atlas y Mnemosine de Warburg, una de sus obras fundamentales. ${ }^{9}$ La idea de Didi-Huberman no fue la de mostrar de nuevo el Atlas sino partir de los conceptos de Warburg y hacer una serie de nuevas propuestas. En ella se mostraban otras series de imágenes, realizadas por artistas muy diversos. En la exposición se mostraba indirectamente el potencial desestabilizador de las ideas de Warburg en la medida en que se señalaban las múltiples maneras posibles de agrupar imágenes con diversas lógicas de agrupación. ${ }^{10}$ Además, poco antes se había realizado una edición en español del Atlas Menmosyne de Warburg con un amplio comentario de la obra por parte

\footnotetext{
${ }^{8}$ Aby Warburg, Werke in einem Band, auf der Grundlage der Manuskripte und Handexemplare (Berlin: Suhrkamp, 2010.)

${ }^{9}$ Georges Didi-Huberman, “¿Cómo llevar el mundo a cuestas?” (Madrid: Museo Nacional Centro de Arte Reina Sofía, 2011).

${ }^{10}$ El texto hablado de las conferencias puede ser consultado online en la página Web del MNCARS, bajo ARCHIVO /CONFERENCIAS /Fechas 4-5 marzo 2011
} 
de Fernando Checa. ${ }^{11}$ Todo lo anterior indica que a pesar de haber transcurrido casi un siglo desde la producción de sus escritos, el proceso de recepción e interpretación de sus ideas está lejos de haber llegado a un punto final. Aun así y dentro de las cautelas que se derivan de la situación descrita, cabe señalar suscintamente algunos de sus conceptos.

\section{Pathosformel}

En primer lugar, el de la Pathosformel (fórmulas del pathos) es el concepto más ampliamente difundido de los análisis ofrecidos por Warburg. Quizás se deba al hecho de que por lo menos, en apariencia, puede ser fácilmente asimilado por las categorías tradicionales de la historia del arte. De todas maneras, un estudio atento de su obra muestra mas bien que ese tipo de asimilación pasa por alto algunos de los aspectos más interesantes del concepto. ${ }^{12}$ En una primera aproximación, se trata de imágenes que por sus características son capaces de transportar los sentimientos más profundos del ser humano. Esta caracterización no se mueve en el plano de la psicología individual. No se trata de las expresiones del dolor individual sino que apunta a un nivel antropológico más fundamental. Según ello, este tipo de imágenes se plasmarían en un tipo de experiencias que surgen de lo más profundo del ser humano.

Para Warburg una de esas experiencias fundamentales es la del dolor. Él constata en sus estudios que este tipo de imágenes se dan con especial intensidad

\footnotetext{
11 Warburg, Aby. Atlas Mnemosyne (Madrid: Tres cantos, Akal, 2010)

12 Exposición, "Die entfesselte Antike, Aby Warburg und die Geburt der, Pathosformel", Cat. Exp. Hamburger Kunsthalle, Hamburg, 2011.
} 
sobe todo en el mundo grecoromano. No comparte las ideas de Winckelmann según las cuales la característica esencial de ese arte sería la expresión de lo "apolíneo "y de la" serenidad". Warburg ha asumido plenamente el pensamiento de Nietzsche según el cual, esa cultura estaría mas bien caracterizada por una dialéctica entre lo apolíneo, por un lado, y lo dionisíaco y trágico, por el otro. ${ }^{13} \mathrm{El}$ arquetipo de esa imagen sería la expresión de dolor en la famosa estatua de Laocoonte. No cabe duda de que una descripción de esta escultura y la de las múltiples imágenes que transportan el sentimiento de lo trágico, puede realizarse de una manera satisfactoria en función de una serie de rasgos estilísticos. Pero para Warburg esto no es lo esencial. Para él, determinadas creaciones del arte, son la consecuencia de la lucha del ser humano para no sucumbir ante los retos de la existencia. Son, por así decirlo, la expresión de la victoria en una pugna en que estaría en juego un proceso de liberación y, de alguna manera, constituirían actos fundacionales de un proceso civilizador. En ellas se transmite una especial energía como fruto precisamente de esa lucha. Una energía que, de alguna manera, se mantiene viva en ellas como una especie de contenedor o recipiente. Lo importante es que esa energía no se pierde con el paso del tiempo. Es posible que se mantenga en un estado de letargo, pero para Warburg existe la posibilidad de que, en determinados contextos históricos y culturales, esa energía se libere de nuevo. Esto es lo que precisamente habría ocurrido en el Renacimiento. Por una serie de circunstancias especiales, en esa época se produjo un redescubrimiento del mundo grecoromano y se habría conectado con esas energías acumuladas produciéndose

13 Walter Busch, "Aby Warburg und y Friedrich Nietzsche, Pathosformel und Sprachgebärde" en: Ekstatische Kunst besonnenes Wort Kofler,Peter, Bozen 2009 y en especial Nietzsche Friedrich "Der Ursprung der Tragödie", (1886). 
su nueva puesta en acción. El mundo del Renacimiento no se dedicó a copiar las imágenes del pasado sino que mas bien se las reapropió en un contexto completamente distinto. Entre otras cosas, aquellas habían surgido en el contexto de la religiónn pagana y la reapropiación del Renacimiento ocurría dentro del mundo de creencias cristianas. Warburg llegó a muchas de sus conclusiones después de hacer estudios detallidísimos de los hábitos, costumbres, fiestas, modos de vestir y las formas de la decoración de los palacios por parte de las familias que impulsaron el arte del renacimiento a partir del siglo $\mathrm{XV}$ de un modo especial en el mundo de los banqueros florentinos.

Esta manera de entender la imagen va más alla del concepto habitual de que el arte es "expresión o reflejo" de una época. Quizás el elemento que permite captar la diferencia de su concepto de la imagen, frente a otros de su tiempo más tradicionales, sea el de la imagen como "energía". Con ello la imagen adquiere, en el conjunto de las prácticas sociales, una función mucho más protagónica.

A Warburg no lo interesa tanto la imagen como "obra de arte", sino, mas bien, le interesa por su capacidad de vertebrar o articular una sociedad determinada. Por eso sus análisis rebasan las categorías tradicionales de la historia del arte y lo sitúan en el campo de una "Kulturwissenschaft", ciencia de la cultura, o en el concepto tan debatido actualmente de una "Bildwissenschaft", ciencia de la imagen. Este enfoque también tiene una serie de ventajas en el momento de estudiar objetos heredados del mundo precolombino, pues evita entrar en la cuestión de si se está dentro del campo del arte o en el campo de la antropologia. La respuesta sería que se trata simplemente de imágenes u 
objetos que nos transportan algo esencial de esa sociedad: en los términos de Warburg, una determinada energía acumulada por esas sociedades. Hay un aspecto muy importante de todas maneras, que aunque será tratado con más detalle en la última parte, conviene ya señalar en este apartado, pues de alguna manera está implícito en todo lo anterior.

Para Warburg, el conjunto de esas fórmulas del pathos se crean en el arte grecoromano. Por eso la gran importancia que tiene para él el estudio y, sobre todo, la conservación de su memoria. Pero en cualquier caso en ningún momento se puede deducir de sus escritos que el arte de otras culturas no pueda ser contenedor de energías equivalentes a las que él constata en el mundo grecoromano. Las diferencias se referirían mas bien a los aspectos formales de la imagen distintas en diversos contextos culturales.

Tomadas las ideas de Warburg en torno a la imagen por el lado de su fundamentación antropológica, se abre un campo nuevo de análisis para otros contextos. El punto de partida fundamental para él es que el ser humano crea imágenes como resultado de un proceso civilizatorio. Quizás las reservas que se puedan derivar de los escritos de Warburg es que no extendiera sus análisis a otras culturas. Abrió sí su foco de análisis incluyendo imágenes de su mundo contemporáneo; en ese campo, tomó en serio las imágenes difundidas en los medios, pero no entró en cambio, a analizar los procesos de apropiación de las culturas africanas que se estaban realizando por las vanguardias de su tiempo en París. Desde la perspectiva de las teorías de Warburg, sería pues, la dimensión antropológica de la imagen tal como queda establecida en la "Pathosformel" la que establece el punto de unión con otras culturas. 
Si se acepta esta premisa como válida, el siguiente paso sería someter las imágenes en cuestión a un proceso de análisis que llevase a detectar las que son portadoras de esos niveles de intensidad requeridos en la Pathosformel. Es posible que este intento inicialmente no sea muy prometedor. Al fin y al cabo nuestros hábitos de mirada y apreciación formal están altamente condicionados por la tradición de imágenes que se ha convertido en hegemónica en nuestra cultura. Habría que tratar de iniciar otras estrategias que permitieran llegar, por así decirlo, a detectar las "pathosformel" específicas, en este caso de las culturas del mundo precolombino. Para ello sería necesario primero liberarlas de su carga de "documento" del pasado, y detectar los rasgos constitutivos de niveles antropológicos profundos que las puedan conectar con el presente. La hipótesis que sustenta el presente ensayo es que la construcción de una nueva mirada hacia el pasado es posible, y que exige estrategias específicas de varios tipos para que esa mirada sea posible. Esta cuestión será abordada en el último apartado.

\section{Nachleben}

El concepto de Nachlebe (pervivencia o supervivencia), son traducciones aproximadas del concepto alemán. La traducción al inglés con la palabra "afterimage" está mucho más cercana al concepto alemán. ${ }^{14}$ La idea fundamental de este concepto es que una determinada imagen se crea en un contexto histórico específico y con unas funciones prefijadas. Estas funciones pueden ser de orden muy variado; por ejemplo, de tipo religioso,

14 Didi-Huberman, L'image survivante: histoire de l'art et temps des fantomes selon Aby Warburg, (París: ed Minuit, 2002 ) 
imágenes relacionadas con el poder, potenciadoras de la memoria familiar, etc.

Es en cada uno de esos contextos históricos y sociales específicos, donde las imágenes tienen su ámbito de actuación. Desde esta perspectiva, las imágenes dejan de tener sentido una vez agotada la realización de las funciones para las que estuvieron pensadas. Lo que normalmente ocurre es que estas imágenes luego, es que entran en un proceso de degradación. Éste a su vez, puede presentar formas muy diversas: la destrucción, el olvido o cualquiera de las muchas formas de desaparición o pérdida de presencia.

En el mejor de los casos, si en épocas posteriores no han sido destruídas pueden ser rescatadas por sus cualidades estéticas y pasar a ser objeto de colección o conservadas por su capacidad de evocar un pasado entrando a formar parte de algún museo o institución equivalente. Pero la idea de "Nachleben, pervivencia", no encaja en ninguna de esas formas de conservación enumeradas anteriormente. Esto no significa que desde estas formas de conservación la imagen en cuestión pueda provocar alguna variante de entre las múltiples formas de pervivencia. El concepto de pervivencia, como rasgo diferencial, implica algún tipo de presencia viva en el nuevo contexto histórico o social en el que se inserta la imagen heredada del pasado. A Warburg lo que le interesa, de modo especial, es la forma de abordar el fenómeno de los legados culturales que conforman la sociedad en un momento dado. El concepto de "pervivencia" en sí mismo tiene algo de escurridizo, no es fácil acotar un campo específico donde se pueda estudiar de modo preferente este fenómeno. El concepto le interesa por ese grado de indefinición, pues así puede abordar las múltiples variantes o formas en que ésta se produce 
independientemente del lugar que ocupa o del papel que juega en el contexto social originario. En algunos escritos elabora la idea de que esa pervivencia es posible porque las experiencias del pasado han sido transmitidas a través del tiempo en un proceso de conservación por la memoria colectiva. Para ello recurre a conceptos biológicos de su época según los cuales, las energías concentradas en las imágenes se almacenan en el cerebro de los componentes de una sociedad constituyendo uno de los elementos de la memoria colectiva. ${ }^{15}$ Estas ideas se conectarían con las de Halbwachs, para quien determinados comportamientos sociales tales como los rituales, las fiestas, los bailes, las conmemoraciones, etc., todas ellas con carácter performático, garantizan procesos de creación y transmisión de memoria colectiva. ${ }^{16}$

A Warburg le interesó de un modo especial la forma como el legado de imágenes del mundo grecorromano siguió viviendo en contextos posteriores por medio de transformaciones o adaptaciones inesperadas. De todas maneras esta vía de análisis de la pervivencia es especialmente exitosa, sólo si se cuenta con un acervo amplio de imágenes heredadas. En estos casos, y esto se da de un modo especial con el mundo de la herencia grecolatina, resulta posible que a pesar de las rupturas y desapariciones puedan detectarse con cierta precisión los

\footnotetext{
${ }^{15}$ El concepto que adoptó Warburg de la biología de su tiempo fue el de "engrama". Es un concepto que no ha recibido una confirmación científica posterior. Sin embargo la neurociencia está aportando actualmente resultados muy novedosos sobre la manera cómo se forman las imágenes en el cerebro.vid. (entre otros), Dresler, Martin "Kunst und Neurowissenschaft" pag. 22-32 en: Dresler, Martin Neuroästhetik: Kunst, Gehirn und Wissenschaft (Lepizig: Dresler Martin, 2009). Independientemente de su fundamentación biológica la idea de la "memoria colectiva" sigue siendo un concepto ampliamente aceptado en la teoría cultural.

${ }^{16}$ Maurice Halbwachs, "Les cadres sociaux de la mémoire", 1929 y "La mémoire collective", Revue philosophique, (mars-avril 1939)
} 
sucesivos procesos de transformación. Por desgracia, estas circunstancias en muy pocos casos se dan en el contexto latinoamericano y menos todavía en el caso especial de Colombia. Los sucesivos procesos de destrucción han sido mucho más amplios, tanto por motivos religiosos o por razones de codicia especialmente intensos en el siglo XIX.

Hay otro aspecto más sorprendente e inquietante que también está vinculado al concepto de "pervivencia" y es el de la pervivencia como "fantasma" o "tiempo fantasmal". Incluso Aby Warburg en alguna ocasión, con un ligero tono irónico menciona que con la "Nachleben" ("pervivencia") trataría de contar "Historias de fantasmas para gente mayor". ${ }^{17}$ La idea o la imagen del "fantasma", explotada de modo preferente en el contexto de la cultura popular tanto en la novela como en el cine sin embargo, contiene elementos que la hacen muy útil para estudiar fenómenos de pervivencia. ${ }^{18}$ Este aspecto ha sido especialmente estudiado por Didi-Huberman. A esa idea se une toda una red de conceptos que evocan formas muy sugestivas de presencia. El "fantasma" se sitúa en el campo de lo difuso, es un tipo de presencia que aun procediendo del mundo de los muertos puede penetrar en realidades inesperadas. Pero el rasgo más sobresaliente es que su actuación como presencia ocurre dentro de una temporalidad completamente imprevisible. La presencia que crea una imagen heredada del pasado está vinculada a la existencia de esa imagen; en cambio "el fantasma" puede evocar tiempos distantes sin que

\footnotetext{
${ }^{17}$ Ver La introducción de Didi-Huberman al catálogo de la exp. del MNCARS, "Atlas ¿Cómo llevar al mundo a cuestas?".

${ }^{18}$ Ver por ejemplo Jacques Derrida, Spectres de Marx, París, 1993. En esta obra Derrida aborda las ideas de Marx desde la perspectiva de su falta de vigencia en esos años, pero que, sin embargo, se podían detectar múltiples restos de su presencia de una forma difusa.
} 
haya una materialidad a la que pueda agarrarse el fantasma. Ello implica una desterritorialización de la imagen y del tiempo. El tiempo de la imagen presente en forma de fantasma no es el tiempo de la historia lineal. Esto significa, pues, que el pasado se puede hacer presente en momentos y contextos muy alejados del lugar originario. El fantasma en muchos casos alude también a un concepto de culpa, al hecho de que puede haber realidades del pasado que reclaman un tratamiento distinto al que han recibido o han dejado de recibir, o un tratamiento debido que, por diversos motivos, se le ha negado. La negación puede ser el resultado de un proceso de represión política. Ésta en muchos casos intenta borrar las huellas de la realidad incómoda para el poder o incluso borrar períodos completos para impedir que se instalen en la memoria colectiva y produzcan efectos desestabilizadores. Como demuestra el transcurso de la historia, esto no se consigue de una manera absoluta, con lo cual se inicia un camino tortuoso de pervivencia, más o menos solapada, más o menos consciente, de esas realidades reprimidas.

Si estas reflexiones se trasladan a lo ocurrido con las culturas precolombinas, con el concepto de pervivencia se abrirían otras vías de análisis que irían más allá de los conceptos habituales de "mestizaje", "hibridación," o "aculturación". Estos conceptos implican más o menos pervivencias que implican cierta linearidad histórica o contacto espacial. El concepto de "pervivencia" como "fantasma" implica en cambio, la idea de un proceso nunca cerrado. El pasado se puede hacer presente en los contextos más imprevisibles. Estos actos de presencia con carácter inesperado y su extraña vinculación con el presente, le quitan a la realidad su carácter de estabilidad definitiva. Por esta vía es posible integrar de un modo más efectivo muchos fragmentos que por su carácter excesivamente fragmentario no permiten reconstruir la totalidad de un proceso o realidad. Se trata de "restos" o 
"residuos" flotantes de otros períodos y de otras culturas. Esta forma de tratamiento les liberaría de tener que integrarse en los discursos canónicos de la "historia del arte" o de los estudios arqueológicos. No porque estos no sean necesarios, sino porque pemitirían crear otro tipo de vínculos.

Por lo demás, esta manera de analizar los efectos de la "supervivencia" está muy emparentada con las reflexiones que surgen desde otros círculos en esos mismos años. En especial hay que destacar las reflexiones de Walter Benjamín en torno a la imagen y su concepto de "imagen dialéctica".

\section{Mnemosyne}

Finalmente, el otro concepto fundamental en su obra es el de Mnemosyne. Nombre que alude a la figura griega de la memoria, sería la idea del archivo como base para crear dispositivos experimentales. Mnemosyne es el título de la última obra de Warburg. Aunque, de alguna manera, la idea nace ya en el año 1904, su elaboración efectiva solo se produjo a partir de 1924, siendo presentada en público en Roma en el año 1928 poco antes de su muerte (1929). Por otro lado, en la intención de Warburg debía ser continuada o sea que se trataría de una obra incompleta. En su versión actual, la obra se compone de un conjunto de unas 3000 imágenes dispuestas en 52 tablas. Actualmente estas imágenes han sido reunidas en forma de libro facilitando su divulgación pero deformando con ello un poco la idea inicial de Warburg, en su concepción estaba pensado de que la agrupación de esas imágenes podía cambiar su composición. Su recepción en el mundo de la historia del arte ha sido muy desigual, tampoco hay acuerdo entre los historiadores sobre la forma adecuada 
de utilización. ${ }^{19}$ En primer lugar, conviene destacar que no se trata de un archivo, ni siquiera de un archivo donde se habrían reunido las imagenes coleccionadas en su famosa biblioteca; el conjunto de imágenes coleccionadas era muy superior en número a las reunidas en su Atlas Mnemosyne. Un archivo, en cambio, aspira a una totalidad, el Atlas de Warburg no constituye en sentido estricto un archivo. Es una selección muy explícita de imágenes. Pero una selección que, por otro lado, sólo es posible hacerla a partir de la existencia del archivo. Las imágenes reunidas en el Atlas proceden de campos muy diversos. Fundamentalmente eran imágenes de la historia del arte, muchas del mundo grecoromano y otras muchas del Renacimiento. En estos casos, las imágenes al ser agrupadas en las tablas del Atlas parecen estar dispuestas con la intención de mostrar una serie de derivaciones, entre ellas, lo que él llama las "migraciones", es decir las transformaciones, ramificaciones, etc., de una imagen primigenia. En no pocos casos, la intención de las diversas agrupaciones es la de mostrar cómo la Pathosformel va presentando transformaciones, ramificaciones, etc.

Pero hay otras líneas de lectura mucho más complejas y en no pocos casos la lógica a partir de la cual han sido agrupadas determinadas imágenes en una tabla sigue siendo muy oscura. Aunque buena parte de las imágenes recogidas en su Atlas proceden del mundo de la historia del arte, sin embargo en otros casos tomó también grabados populares, imágenes de sellos, postales,

19 Sobre el Atlas Mnemosyne, ver La introducción de Didi-Huberman al catálogo de la exposición de Madrid en el MNCARS,2011 y la introducción de Fernando Checa a la edición española de Warburg, Aby Atlas-Mnemosyne. ed Akal Madrid 2010, también los diversos estudios de Weigel, Sigrid "Die Kunst des Gedächtnisses, das Gedächtnis der Kunst: zwischen Archiv und Bilderatlas" pg. 99-121, en Flach, Sabine "Bilderatlas im Wechsel der Künste und Medien” ed. Sabine Flach, ed. Trajekte, München,2005. 
fotos de revistas sobre acontecimientos de la época, etc. Con el advenimiento de la Primera Guerra Mundial, hizo también un inmenso acopio de imágenes con el tema de la guerra, pero que al final no entraron a formar parte de su atlas, probablemente con la idea de crear otra obra en relación con esa temática más limitada. Las tablas de Warburg tienen aparentemente la estructura de un cuadro pero en realidad subvierten la idea tradicional de un cuadro. Este con la protección del marco crea un campo de inteligibilidad y conecta en general lo contenido en el cuadro como una imagen única. El Atlas en cambio trastoca estos marcos de inteligibilidad. El mismo Warburg cambiaba con frecuencia las imágenes en la tabla y la disposición de las tablas entre sí, pues la manera de mostrar sus tablas no era colocarlas en la pared sino disponerlas en medio del espacio.

Las imágenes en la tabla es cierto que sugieren ciertas líneas de lectura, pero éstas nunca se imponen como algo definitivo. Son lecturas en las que el trabajo de la imaginación juega un gran papel y ésta a su vez trabaja de un modo más transversal. Los espacios de sentido siempre están amenazados por el fondo negro sobre el que están insertadas las imágenes, con lo cual el dispositivo creado por Warburg señala que el sentido nunca es total, sino que siempre está constituido también por procesos de ruptura y discontinuidad. Las rupturas dan un cierto carácter de fragilidad al saber originado por una determinada lectura.

Por otro lado, Didi- Huberman ve en este tipo de montajes presentado por Warburg un claro parentesco con lo que estaba ocurriendo en esas fechas con la imagen fílmica en Vertov y Eisenstein o con los trabajos de Moholy-Nagy y Bataille. Frente a una corriente interpretativa que ve en el Atlas de Warburg una especie de ilustración de sus ideas, otros investigadores destacan la idea de que consiste mas bien en una herramienta de 
trabajo. Entre otras cosas se trataría de juntar imágenes que promueven un determinado tipo de investigación y que mostrarían también cómo actúan las imágenes.

La oposición entre Arhivo y Atlas tal como la entiende Warburg, también es muy pertinente para enfocar la situación actual. En una situación en que las herramientas digitales han creado la posibilidad de crear un Archivo monstruoso, cada vez más inabarcable, la idea del Atlas supone crear un repliegue para posibilitar segmentos del saber que sirvan como orientaciones ante las preguntas que se plantean de una manera real en una comunidad cultural determinada.

\section{5. (Re) Construcción de la Memoria Nacional-La Regeneración y Alberto Urdaneta.}

Los procesos de turbulencia que siguieron a las guerras de la Independencia crearon pronto la necesidad de una consolidación que a su vez fuera acompañada de una interpretación de lo ocurrido. En lo que se refiere a la historia de Colombia hay un consenso general en considerar que la generación o el movimiento de la Regeneración inicia una etapa de consolidación nacional de larga duración. Este movimiento bajo el signo de un gobierno conservador se instauró con la voluntad de asentar el país con la ayuda de una nueva reestructuración institucional y cultural. En lo que se refiere a la construcción del relato de la nación, de una manera simplificada, se puede afirmar que se instala la visión de un pasado construído desde la perspectiva de las élites de entonces, un sector de la sociedad que se consideraba heredero y dueño de lo alcanzado como consecuencia de la independencia nacional.

Por esas fechas el período colonial ya no se veía como una realidad antagónica a la creada por la República. 
Eso permitía que bajo un régimen republicano esa clase se viera como la continuadora del orden instaurado desde la Conquista con un predominio racial de lo español y un esquema de valores totalmente vinculado a la doctrina y moral de la iglesia católica. El tomar como punto de partida la Regeneración se justifica, pues, por la centralidad que ocupa este discurso histórico como elemento conformador de la sociedad colombiana, o por lo menos, de una parte de ella. ${ }^{20}$ En este contexto las preguntas planteadas son: ¿Establece la Regeneración alguna relación con el pasado precolombino? En caso positivo, ¿qué tipo de relación? ¿Cuál es la situación actual con ese pasado después de los cambios ocurridos al respecto a lo largo del siglo XX, también en el discurso histórico? ¿Cuáles podrían ser las estrategias para cambiar la relación con ese pasado en el caso de que se mostrara que la situación es insatisfactoria?

La conciencia de la necesidad de fijar e interpretar lo ocurrido para dar constancia de ello ocurre recién terminados los acontecimientos que determinaron el proceso de la independencia. En 1827 José María Restrepo publicó en París diez volúmenes con el título Historia de la Revolución de la República de Colombia. La construcción de un nuevo orden político implicaba también la creación de un relato histórico que cada vez más va conformando el relato de la "nación colombiana". El nuevo orden republicano exigía una recomposición de las nuevas piezas y el rechazo de las anteriores. Este

${ }^{20}$ Sobre la historia de Colombia, entre otros muchos David Bushnell, Colombia, una nación a pesar de sí misma, (Bogotá: Ed. Planeta, 2000) y Ensayos de historia política de Colombia, siglos XIX y XX (Medellín: Ed. Carreta, 2006) Sobre la Regeneración, en especial, María Pilar Acosta, El lenguaje político de la Regeneración en Colombia y México; María Pilar Acosta, ópera eximia, Bogotá, 2010, y Leopoldo Múnera Ruiz, Regeneración visitada: pluriverso y hegemonía en la construcción del estado-nación en Colombia, (Bogotá: Universidad Nacional, 2011) 
rechazo se interpretaba como un corte y negación de las estructuras heredadas del período colonial. Así por ejemplo, Restrepo habla de ese período como un tiempo de "esclavitud degradante". ${ }^{21}$ Pero ya en la segunda edición de su historia en 1858, se abría una puerta para incluir el período colonial en el relato de la nación colombiana.

El papel creciente que jugó la iglesia católica como vertebradora de la nueva unidad nacional hacía inevitable que se procedieran a buscar líneas de continuidad entre el orden republicano y el colonial. A pesar de la existencia de grupos liberales, las clases dirigentes de la sociedad, en gran parte, eran herederas de los sectores que durante la colonia habían manejado los recursos económicos locales con ligámenes de todo tipo con los funcionarios virreinales. Sin embargo, el proceso de estructuración política sobre bases republicanas era irreversible, por lo tanto la recuperación del pasado tenía que hacerse incorporando el sistema de valores anterior. En especial con el predominio indiscutible de la herencia española como núcleo de la nueva nación republicana refuncionalizada como "lo colombiano".

A pesar de los avatares a lo largo del siglo XIX debidos a las contiendas entre liberales y conservadores, cuando se inició el movimiento de la Regeneración, con la entrada de los conservadores en el poder en 1880, estos se consideraron suficientemente asentados en el poder, de tal manera que pueden emprender la tarea de dar bases más estables a la nación más allá de las puras instituciones políticas. Esta seguridad no se derrumba a pesar de que en ese período se producen los dos acontecimientos que dejaron traumas de larga duración, "La guerra de los mil días" y la pérdida de Panamá.

${ }^{21}$ Alexander Betancour, Historia y Nación (Medellín: La Carreta editores, 2007) 
Entre las instituciones que van creándose en este período pueden mencionarse entre otras: en 1871 se establece la Academia Colombiana de la Lengua; en 1886 la Academia de Bellas Artes; en 1887 La Academia Colombiana de Ingenieros; en 1902 la Academia Colombiana de Historia. Especialmente influyentes son la Academia de la Lengua, con su concepción de la corrección del lenguaje en lo que tiene de proceso disciplinador, y la Academia de Historia, cuyos miembros con frecuencia pertenecían a familias descendientes de procures; en ella se preparaban los programas de historia para las escuelas y también la formación de los maestros.

En el plano ideológico, una de las figuras más sobresalientes de este período es la de monseñor Rafael María Carrasquilla (1875-1930). De 1891 a 1930, casi cuarenta años, ocupó el cargo de rector del Colegio Mayor del Rosario, la institución con más influencia en la formación de los hijos de las clases dirigentes. En su doble condición de eclesiástico y de persona perteneciente a esa clase, podía afirmar como algo en apariencia evidente que "dos cosas forman la patria, el suelo en que vivimos y la raza a que debemos nuestro origen y más cerca nos pertenece el linaje que el territorio. Más satisfacción nos causa a nosotros el recuerdo de las glorias españolas que el de las hazañas de cualquiera de los caciques que mandaron en estas tierras antes de ser descubiertas por Colón". ${ }^{22}$ Lo curioso de esta declaración es que aparezca de una manera explícita el hecho de que otros antes de Colón mandaron en el territorio y luego se hable de la raza a la que debemos nuestro origen refiriéndose a la española, sin percibir la contradicción implícita en su afirmación. Un ejemplo de la pervivencia de las herramientas doctrinales creadas en este período es la Historia de Colombia, el texto oficial para la enseñanza

${ }^{22}$ Alexander Betancourt, Historia y Nación... 
secundaria. Gerardo Arrubla lo escribe en 1910 y estuvo vigente como texto hasta el año 1984. La figura de Alberto Urdaneta (1845-1887) representa sin duda, un lugar muy especial dentro del proceso de la Regeneración. No ocupó cargos públicos, pero a cambio puso en marcha una serie de importantes iniciativas en el campo de la cultura tanto en su papel de mecenas como en su papel de empresario. Entendió como nadie la importancia de las imágenes para generar y fortalecer el cuerpo de la nación, su estancia en París en los dos períodos de 1865 a 1868 y de 1877 a 1881 le puso en contacto con la existencia en ese país de una abundante cantidad de revistas ilustradas. Esta experiencia tuvo mucha relevancia a lo largo de sus años de actuación en el campo cultural. Gran parte de sus esfuerzos los dedicó a crear y sostener revistas, actividad que inició durante su estancia en París. En este sentido, la creación de varias publicaciones ilustradas hay que verlas como un fenómeno importante de modernización del país en consonancia con lo que estaba ocurriendo en países como Francia e Inglaterra con su gran cantidad de prensa ilustrada. ${ }^{23}$

El poder de difusión de imágenes a través de las revistas posibilitado por las nuevas técnicas de impresión podía contribuir grandemente a cohesionar la sociedad y al mismo tiempo fortalecer la idea de nación colombiana, tal como se pretendía fraguar desde la Regeneración. La nueva nación no contaba con un abundante patrimonio de imágenes y éstas eran necesarias como articuladoras de la memoria colectiva.

Urdaneta abordó el tema de las imágenes desde varios frentes. En primer lugar está el campo de las imágenes que surgen del mundo del arte. La situación

${ }_{23}$ Jean Pierre Bacot, La presse illustrée au XIX siècle (Limoges: Pulim , 2005) 
de Colombia era muy deficitaria, pues no contaba con la institución adecuada para formar artistas de calidad. Uno de sus empeños mayores fue el de que se creara una Academia de Bellas Artes. Por otro lado, él, a título personal, reunió una importante colección de pinturas y se encargó de organizar exposiciones en salones nacionales.

Pero donde concentró su mayor interés fue en la creación de una revista ilustrada capaz de difundir reproducciones de imágenes con calidad. Por ello, en su segundo viaje adquirió la maquinaria correspondiente para ponerla en marcha de inmediato a su regreso. También creó un equipo de dibujantes y grabadores capaces de ir suministrando las imágenes que la revista requería. El resultado de este esfuerzo fue la publicación de la revista llamada Papel Periódico Ilustrado, que se publicó de 1881 a 1887, año en el que falleció, con algún número póstumo en fecha posterior.

No es el objetivo dentro del marco de cuestiones del presente ensayo, entrar a realizar un análisis pormenorizado de las diversas imágenes publicadas a lo largo de su existencia y en qué medida estas imágenes refuerzan el programa de construcción de un discurso de la Nación desde la perspectiva de la Regeneración.

$\mathrm{Si}$ en cambio, conviene detenerse en una determinada imagen porque ella contiene de una manera muy concisa muchos de los elementos mencionados hasta ahora en lo referente al discurso de la Regeneración, de modo especial la peculiar visión del pasado nacional. Se trata de la imagen de la cabecera del Papel Periódico Ilustrado (Imagen 1). Es una imagen creada exprofeso para tal función. En primer lugar, de una manera general se puede decir que es una imagen muy compleja, presentando los rasgos de una imagen alegórica. Como tal no es una imagen que parta de un objeto o realidad concreta, es más bien una imagen sintética que reúne 
rasgos y atributos de realidades muy diversas. El acoplamiento de esas diversas partes se hace de una manera muy creativa. Todas las partes se unen para representar una idea abstracta. Como se verá, se trata de la idea de la "nación colombiana". El lugar ocupado en la revista está destinado a darle una visibilidad especial $\mathrm{y}$, de alguna manera, mostrar de manera intuitiva, cómo hay que entender y leer la revista. Por otro lado, el hecho de que apareciera en cada número debería contribuir a que se fijara de una manera permanente en el recuerdo de los lectores.

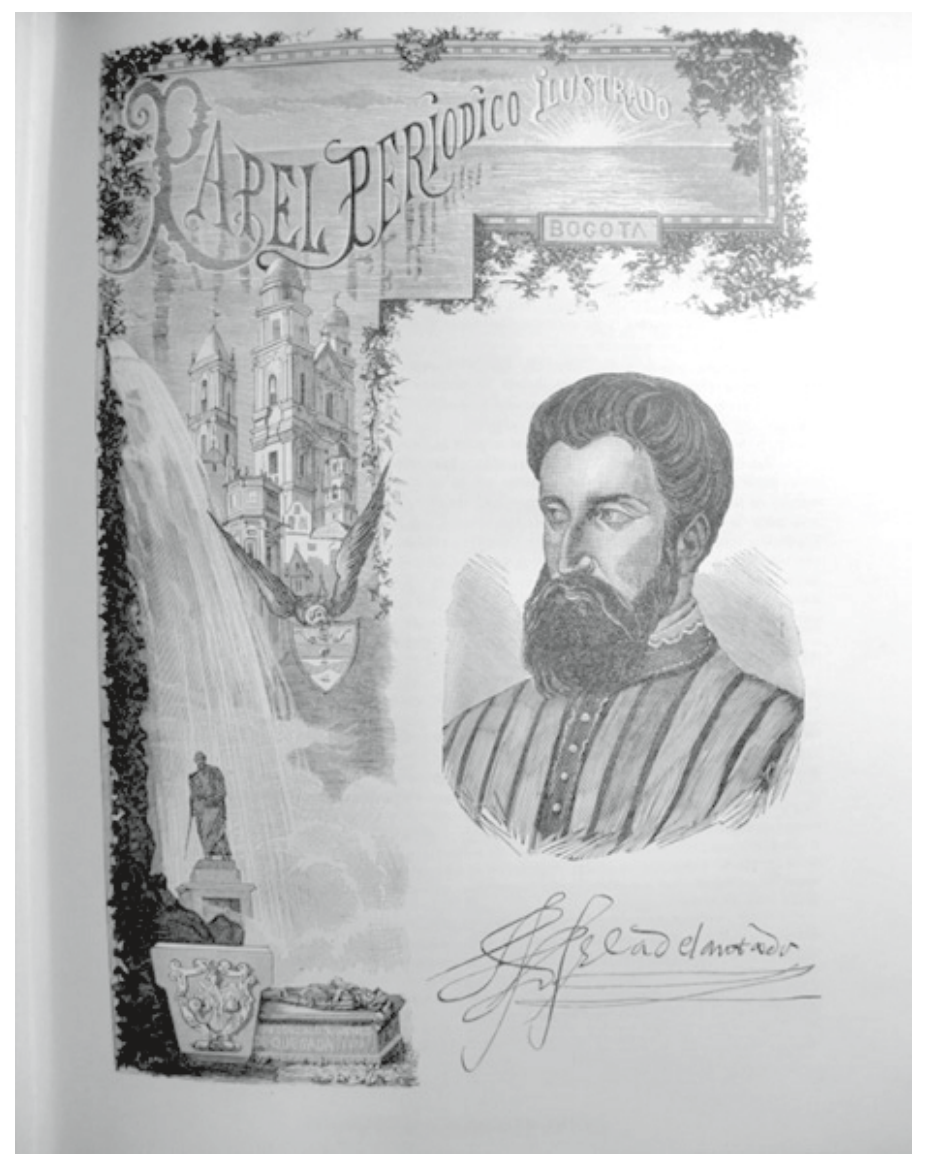

Imagen 1. "Papel periódico Ilustrado " Portada 
La memoria cultural en Warburg y las limitaciones de la construcción de la memoria nacional en Colombia: el regeneracionismo y el pasado precolombino

Es un montaje de imágenes, curiosamente un procedimiento utilizado por Warburg en sus tablas del Atlas Mnemosyne (Imagen 2).

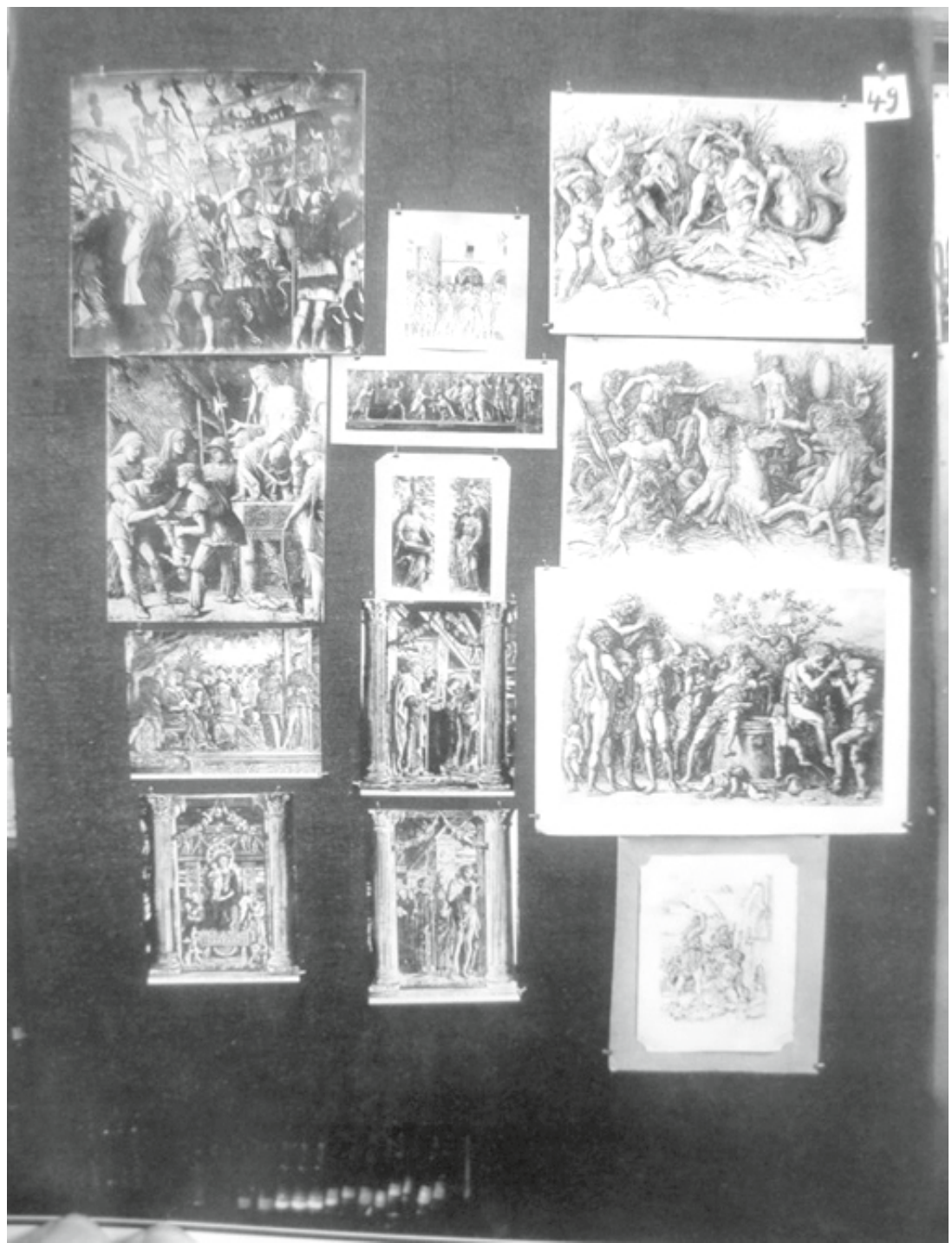

Imagen 2. Atlas Mnemosyne, Tabla n. 49 Aby Warburg. 
Pero hay una diferencia importante en los procedimientos. En la imagen de Urdaneta no hay rupturas ni discontinuidades, esos espacios en negro que en Warburg abría la dimensión de la apertura y la inseguridad. En la imagen de Urdaneta en cambio, todo parece unirse en una continuidad armoniosa, paisaje, figuras, arquitectura, épocas pasadas, presentes y futuras, formando una sola imagen. Se sugiere en la imagen que en ella están contenidos los elementos más importantes que conforman la nación. Descritos de abajo a arriba que a su vez, construye también en la idea de Urdaneta una secuencia temporal, se muestra a la izquierda un escudo sobredimensionado de Bogotá, junto a él la tumba de Gonzalo Jiménez de Quesada, conteniendo su nombre y la escultura de su cuerpo sobre ella. Por encima de ella, a la izquierda, surge la estatua de Bolívar, (la escultura de Tenerani), sobre un alto pedestal cuya parte inferior queda oculta, es decir, no se puede saber dónde se apoya, pero se sugiere que hay una continuidad espacial entre la tumba de Jiménez de Quesada y la de Bolívar, como si la estatua de Bolívar fuera una derivación casi natural de ella. La indefinición espacial viene del hecho de que por detrás de Bolívar se despliega un gran salto de agua, que hay que suponer que es una alusión a uno de los íconos nacionales: el Salto del Tequendama (Imagen 3). 
La memoria cultural en Warburg y las limitaciones de la construcción de la memoria nacional en Colombia: el regeneracionismo y el pasado precolombino

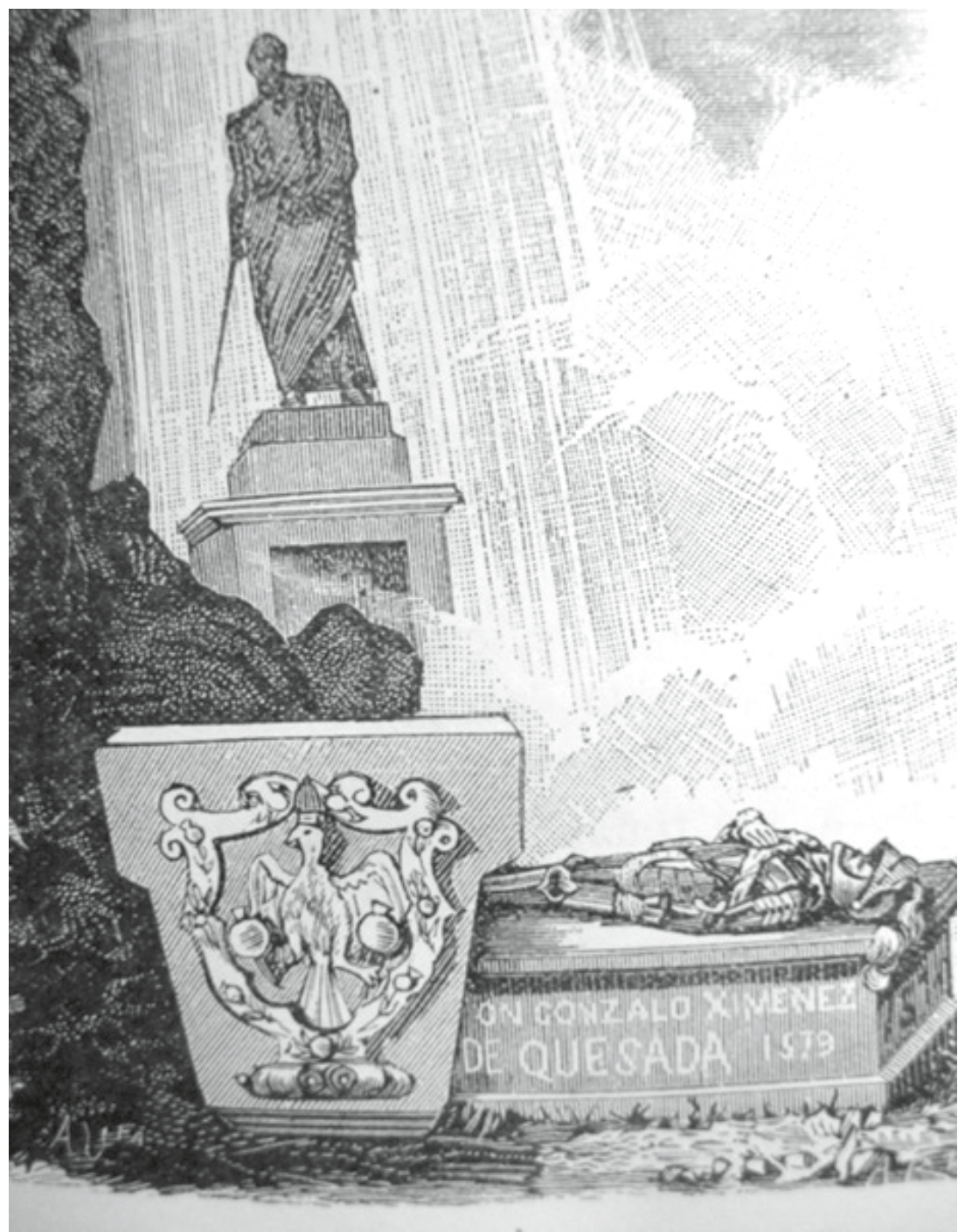

Imagen 3. Papel Periódico Ilustrado. Detalle de la portada parte izqui. inferior

El Salto origina a su caída un conjunto de nubes cubriendo este tramo dedicado a la naturaleza colombiana como un gran telón de fondo que ocupa una buena parte de la superficie de la imagen y que de alguna manera es el elemento de unión entre todos los componentes. En la parte inmediatamente superior al paisaje, surge 
lo que podríamos llamar "las instituciones": la iglesia, en forma de unas torres que pueden ser las de la catedral; otra torre de menor altura pero claramente diferenciada, es la torre del observatorio, sería la ciencia y el progreso. Todo ello se corona con una gran superficie que se extiende horizontalmente a la derecha para abarcar una buena parte del ancho de la página. Esta superficie es la de un mar tranquilo y apacible, como insinuando un presente y un futuro sin fin dominado por el sol resplandeciente que se levanta. En el centro de la imagen hay un elemento dinámico muy interesante, que se junta al dinamismo del salto de agua: es el escudo nacional, elevándose gracias al movimiento extendido hacia arriba de las alas del cóndor heráldico.

El modo como han sido reunidos los diversos elementos sin duda posibilita otras lecturas. Para los efectos de la cuestión aquí planteada de la construcción de la historia, es preciso profundizar la solución adoptada para los elementos que forman la base de la alegoría. Por un lado, el escudo de Bogotá como un resumen de todo el país. Luego está la tumba de Quesada colocada de tal manera que entre ella y la estatua de Bolívar no hay ningún tipo de ruptura: parece que la conquista, y lo que de ella se deriva, la colonia, o el virreinato, y Bolívar y lo que de ello se deriva, la república independiente, hay una continuidad sin suturas. Además, las dos figuras están dispuestas como si se mirara cada una en el espejo de la otra. Pero lo más sorprendente es que la historia del país sólo se inicia con la presencia de los españoles, en este caso simbolizada con la tumba de Quesada. Además visualmente el carácter fundacional se refuerza por el hecho de que la tumba en su posición horizontal ocupa toda la franja inferior de la imagen constituyéndose como un pedestal sobre el que se apoya todo el desarrollo posterior. En esta representación, los siglos anteriores de historia del país, simplemente no existen. La población autóctona no aparece, ni siquiera 
en el papel de derrotada o de comparsa de lo que ocurre con la llegada de los españoles. El suelo donde está colocada la tumba es un suelo aseptic, no alude a nada en concreto, una especie de punto cero del espacio y del tiempo. ${ }^{24}$ La imagen comentada está muy pensada, no hay nada dejado al azar, todo ocupa el puesto que debe ocupar. Desde la perspectiva histórica actual es una imagen inquietante, entre otras cosas, por la atmósfera de serenidad y armonía que transmite y por otro lado, por la violencia de las exclusiones que oculta. El relato nacional creado en el siglo XIX de modo especial desde el programa de la Regeneración no ignora la existencia de ese pasado precolombino, simplemente lo que ocurre es que en esa visión el pasado queda de alguna manera anulado e integrado en una nueva realidad: la que surge con el implantamiento de los patrones culturales y religiosos como consecuencia de la conquista.

El conjunto de artículos y de imágenes que conforman la revista a lo largo del período de su existencia se atienen estrictamente a este relato. Llama la atención, por ejemplo, el amplio espacio que se dedica a la reproducción de retratos de próceres. Hay que interpretarlo como una urgencia percibida por Urdaneta: con el transcurso de los años desde las guerras de la independencia se corría el peligro de que fueran olvidados. En ese contexto, hay que situar los esfuerzos del Papel Periódico Ilustrado y de otras series creadas por esos años.

Hay otros grupos de imágenes, monumentos, arquitecturas, paisajes, etc., muchos de ellos vinculados a los momentos fundacionales de la república. Pero

24 Ver en la Colección de la Academia de la Historia el cuadro de Quijano Montero, "Fundación de Santa Fé de Bogotá", 1938; en él, en una posición marginal, aparecen varias figuras de indígenas alguna de ellas mostrando una actitud entre distanciada y escéptica ante lo que ocurre en el centro de la escena. 
curiosamente también hay algunas contribuciones, aunque pocas, sobre descubrimientos de monumentos y objetos precolombinos, una realidad que había sido excluída del relato de la nación. Sin embargo, aunque fuera de modo marginal, cada vez se hacía más presente en el transcurso del siglo XIX, un siglo en que los diversos países de Europa aprendieron a mirar su propio pasado, coleccionando con pasión sus objetos en los museos y cultivando las diversas disciplinas históricas

En Colombia estos objetos del pasado precolombino creaban todavía cierta incomodidad a la hora de describirlos y de coleccionarlos. Se ignoraba casi todo de ese pasado y por ello las descripciones eran muy pobres. Muchas veces el descubrimiento se realizaba de mano de los extranjeros que visitaban el país. Esta mirada exterior, en no pocos casos, es la que impulsaba la actividad de búsqueda desde el interior. Es significativo que cuando se inician en la segunda mitad del siglo, las exposiciones internacionales en Europa y Estados Unidos, en general se consideraba que la mejor representación de Colombia podía conseguirse mostrando objetos de las culturas precolombinas, se percibía que con ello se cosechaba prestigio. Esto lleva a la paradójica situación de que esta imagen que se llevaba al exterior seguía siendo extraña en el propio país, donde dominaba la versión patriótica de la nación con un marcado acento de lo español y lo católico. ${ }^{25}$ Existían coleccionistas colombianos pero en el conjunto de lo que ocurría en el país se trataba de auténticas excepciones. Entre ellas cabe destacar la de Leocadio Marías Arango (1831-1918) y la de Vicente Restrepo Maya (1837-1899). Lamentablemente lo que predominaba era la guaquería, que llegó a convertirse

${ }^{25}$ Clara Isabel Botero, El redescubrimiento del pasado prehispánico de Colombia; viajeros, arqueólogos y coleccionistas 1820-1945 (Bogotá: Instituto colombiano de Antropología e Historia.Universidad de Los Andes,2006). 
en una actividad económica reconocida socialmente en regiones como Antioquia y Caldas. Se recogían objetos y se saqueaban tumbas para vender lo encontrado en algunos casos a coleccionistas extranjeros, pero en mayor número se buscaban objetos de oro para venderlos por su valor de material precioso. Una práctica que se prolongó hasta por lo menos bien entrado el segundo decenio del siglo XX. En 1923 se fundó el Banco de la República que obtuvo un cierto monopolio en la adquisición de los objetos de oro encontrados en el país. Algunas investigaciones apuntan a que por lo menos en la primera etapa el banco siguió tratando los objetos adquiridos como material para ser fundidos en lingotes. ${ }^{26}$ Fue la intervención de Paul Rivet, gracias a su amistad con el presidente Eduardo Santos, la que consiguió que por fin se preservaran los objetos adquiridos y se coleccionaran como patrimonio de la nación.

No menos interesante es lo que ocurrió con la institución por excelencia encargada de preservar y coleccionar la memoria nacional. En 1823 se crea un nuevo museo que empezó siendo un museo de Historia Natural. Lentamente fue decantándose en el sentido de convertirse en un museo de historia, sobre todo coleccionando objetos relacionados con las guerras de la independencia. Pero en esta primera fase, tuvo una vida sumamente lánguida hasta llegar casi a su total desaparición. En 1879 se rehizo de nuevo con la denominacion de "Museo de monumentos patrios y antiguedades históricas", se mencionaba también el rubro de preciosidades históricas y producciones nacionales. Se produjo en esta época un interés creciente por adquirir objetos precolombinos y hubo varios intentos de compra de alguna colección importante; se consiguió

${ }^{26}$ Carlos Rincón, Consideraciones morales sobre el Museo del Oro del Banco de la República ( en prensa). 
al fin la de Nicolás Pereira Gamboa, pero aun así las colecciones del museo eran basante inferiores a las de los coleccionistas privados de Medellín. En la clasificación de Fidel Pombo, conservador del museo de 1894 a 1901, los objetos se dividían como pertenecientes a: A) historia natural; B) monumentos de historia patria, arqueología y curiosidades; C) coleccción de pintura. El apartado B es donde hay que situar los objetos precolombinos, en este caso cerca, pero aún fuera del apartado "historia patria". En la primera guía de 1881 había las siguientes clasificaciones: A) objetos de la conquista; B) objetos de la colonia; C) objetos de la independencia; y D) objetos y curiosidades indígenas. De nuevo seguía la indefinición quedando lo precolombino en una zona ambigua al modo de los gabinetes de maravillas y curiosidades del barroco que estaban hechos con otra intención, es decir, no desde la perspectiva de una mirada histórica. En sucesivas ediciones de las guías aparecía el concepto de "Historia y Antigüedades", que aparece también en títulos de revistas y en la denominación de la Academia de Historia cuando se creó en $1902 .{ }^{27}$

A pesar de la indefinición institucional frente a ese pasado, cada vez eran más frecuentes los estudiosos e investigadores colombianos que dedicaban su atención. No es el objetivo de ese ensayo hacer una crítica o una valoración de lo realizado al respecto, se trata mas bien de señalar algunos de los cauces por los cuales poco a poco se iba abriendo paso la presencia de ese pasado. Frente a empresas tan valiosas como la Comisión Corográfica, dirigida por Codazzi y su equipo, bajo un gobierno liberal, contrasta la desidia de gobiernos posteriores que toleraron e incluso ampararon la destrucción de ese

${ }_{27}$ Amada Carolina Pérez Benavides, "Las representaciones de la nación en América Latina, siglos XIX y XX", en Memoria y Sociedad N. 28 (enero,junio 2010): 85-106. 
patrimonio. Habría que esperar hasta el año 1931 en que de nuevo bajo un gobierno liberal se promulgó una ley de protección del patrimonio frente al expolio de los guaqueros.

Aunque no fue el primer investigador europeo, hay un acuerdo en general en señalar que la llegada del etnólogo Paul Rivet, en 1939, supuso un salto cualitativo en todo el planteamiento de lo relacionado con las culturas indígenas tanto las de su tiempo como en todo lo que se refería a la preservación del patrimonio del pasado. Con el apoyo del presidente Eduardo Santos, Rivet pudo conseguir que su labor fuera mucho más allá que la labor meramente científica. A partir de él se sientan las bases institucionales para dar continuidad y sistematicidad a los trabajos iniciados. En 1941 se crea el Instituto Etnológico Nacional. Los trabajos de Rivet se vieron reforzados por los procesos puestos en marcha ya desde 1936 en la Escuela Normal Superior. En 1944 las colecciones del Banco de la República pasaron a constituir el Museo del Oro. En 1952 se creó el Instituto colombiano de Antropología y así sucesivamente se podrían enumerar los diversos pasos que se han dado desde entonces hasta el momento actual.

Desde la perspectiva de las cuestiones planteadas, lo más relevante es señalar que a partir de esa institucionalización el pasado tiene un tratamiento público garantizado y que, de alguna manera, pasa a ocupar un determinado espacio en la construcción del discurso nacional. Sin embargo, esta nueva situación deja todavía muchas cuestiones pendientes.

Retomando el punto de partida de la construcción del discurso de la nación creado en la Regeneración, la pregunta central es si las exclusiones que condicionaron ese discurso han desaparecido por el simple hecho del reconocimiento de ese pasado. En la última parte se 
pretende abordar de una manera tentativa esta cuestión, poniendo en juego varias de las ideas elaboradas en la primera parte al exponer los conceptos de Warburg en torno a la imagen y la posibilidad o necesidad de crear otro tipo de relaciones con el pasado, que fueran más allá de lo conseguido hasta el presente.

\section{Relación entre archivo y memoria: los "fantasmas" se abren paso}

Los trabajos en relación con el Atlas Mnemosyne partían en el caso de Warburg de una diferencia clara entre las estrategias del Atlas Mnemosyne y las del Archivo. El concepto de Archivo tal como se usa en este contexto comprende no sólo lo que se entiende por "Archivo" cuando se habla por ejemplo del "Archivo de la Nación", sino en general también de todos los conocimientos adquiridos a través de las diversas disciplinas históricas y también todo lo conservado en las diversas colecciones como museos, monumentos, etc. y otras instituciones afines. Si el concepto de Atlas Mnemosyne lo entendemos como "procesos de construcción de memoria colectiva", está claro que a pesar de establecer una diferencia entre ambos sigue habiendo una relación fuerte: si no se conservara absolutamente nada del pasado no existiría la posibilidad del Archivo y ante el vacío total de huellas o restos, tampoco existiría ningún tipo de memoria. En este sentido, cuando de trata de la reconstrucción del pasado es imprescindible el trabajo sistemático destinado a recuperar el conocimiento del pasado, que comprende los diversos procesos de descubrimiento, salvamento, reconstrucción, estudio, clasificación, colección y exposición de objetos, huellas, etc.; y todo esto abordado desde los diversos campos disciplinares. Y en la medida en que estas colecciones van destinadas a constituir museos, éstos se hacen con criterios parecidos. La única salvedad es que frente al estudio científico, éstos tienen 
que resolver el problema de la "presentación" que plantea otras cuestiones. De todas maneras, con los museos ya se entra en una zona intermedia de los problemas que presenta el Archivo, entendido en su sentido amplio, pues los museos nacen con una voluntad de conexión con el público en general y en su intención está el objetivo de crear una memoria compartida o por lo menos contribuir a ella. De hecho, con frecuencia los grandes museos de arte, directa o indirectamente, son museos de la "historia nacional". Con ello se logra una circulación constante del pasado en la vida de la sociedad y una consolidación de la memoria colectiva.

Con estas indicaciones no se agotan ni mucho menos las múltiples funciones que pueden ejercer, sobre todo en un contexto de turismo internacional, por un lado y, por el otro, en el contexto de las crisis de lo "nacional"," por lo menos de lo "nacional" como ha sido recibido en herencia del siglo XIX. Independientemente de su mejor o peor calidad, por el simple hecho de existir, si son aceptados por el público, pueden convertirse en artefactos de memoria pues pueden ser visitados, comentados, recordados, etc; es decir, forman parte de la vida de la sociedad y crean algún tipo de incorporación con ella. Claro que la mayor o menor conexión con el público y la intensidad de esa conexión son cuestiones cruciales.

Por el lado de la etnografía y la antropología pueden producirse también enfoques especiales que de alguna manera sus resultados trasciendan los límites de la disciplina y conecten con los problemas de la memoria de los grupos étnicos estudiados. Entre otros muchos cabe situar en esta línea de preocupaciones los trabajos de Reichel-Dolmatoff y de Johanne Rappaport. ${ }^{28}$

28 Gerardo Reichel-Dolmatoff, Beyond the milky way,UCLA L.A.California, 1978; y Goldwork and shamanism (Medellin: Colina, 1988) Rappaport, Johanne "Politics of memory" Duke, University press 1998 
Los problemas que se plantean en torno a la relación entre el archivo y la memoria son varios. En primer lugar, no todo lo conservado en él puede entrar a formar parte de la memoria, simplemente por el exceso de información, o sea que a un nivel puramente cuantitativo se produce una selección. Pero además, hay otros procesos más sutiles en esa relación. Los procesos de construcción de memoria son un posicionamiento activo de la sociedad, que se producen de una manera más o menos consciente. Ahí está el hecho, entre otros muchos, que una determinada propuesta de memoria de un museo puede ser rechazada por la sociedad haciéndole poco caso, o puede visitar el museo y asumirlo de forma distinta a la planeada por la institución. Todo lo anterior se limita a la cuestión de cómo desde las formas corrientes de trabajo del Archivo se genera la memoria.

Pero hay también otras vías más sutiles que funcionan almargen de lo programadoinstitucionalmente. A partir de Waburg estamos más sensibilizados para los otros aspectos de la producción de memoria derivada de realidades más difusas. Aquí entrarían en juego los conceptos de "pervivencia", "fantasmas", "huellas", "restos" expuestas en el segundo apartado. De una manera esquematizada, todas estas cuestiones podrián ser reducidas a las siguientes preguntas: A) Cómo los objetos coleccionados o estudiados pueden pasar a formar parte de la memoria colectiva. B) Qué otros procesos o realidades no observados ni estudiados por las instituciones del Archivo pueden intervenir en la formación de la memoria colectiva.

Estas cuestiones no tienen una respuesta fácil y menos en un estudio de carácter limitado como el presente. Pero aunque sea sólo a modo de hipótesis hay que abordarlas, exponiendo algunos aspectos previos de carácter muy amplio que pueden por lo menos apuntar 
en qué dirección se puede crear un espacio propicio para esbozar algunas respuestas.

La primera es la cuestión de las posibles limitaciones en la confección de algunos aspectos del Archivo. De un modo especial, la cuestión de si en el relato de lo ocurrido en la llamada "conquista" no se parte de un esquema demasiado rígido. Más o menos se da por sentado que los procesos de destrucción de las culturas autóctonas, además de la violencia física inmediata derivada de las contiendas armadas, se habrían producido también procesos de destruccción de su sistema de valores y creencias. El relato tradicional, que está avalado por una determinada lectura de los datos que se disponen, parece confirmar esta visión. Sin embargo, cabe plantearse la cuestión de si no es un relato hecho desde la perspectiva del conquistador. Significativamente, no se plantea la pregunta de si la otra parte, es decir, la gran mayoría de la población lo vivió exactamente de la misma manera. Se da por evidente que aparte de una mayor o menor resistencia militar, a esa población no le quedó otra posibilidad que la de asumir un rol pasivo ante los cambios o imposiciones que le venían de un grupo muy minoritario ajeno a ella. Se da por hecho que, en un plazo más o menos rápido, con la dominación también se cortaron en la población autóctona todos los procesos de memoria de lo propio.

Pero existen ya algunos estudios científicos que ofrecen otra versión de lo ocurrido. La etnohistoria ha mostrado que la relación de las culturas precolombinas con la nueva realidad impuesta por la conquista no es tan simple. En el caso de México, donde se cuenta con estudios sistemáticos gracias a la abundante documentación escrita sobre todo entre los Nahuas, se ha podido demostrar que incluso dentro de los procesos de imposición de la nueva cultura, los pueblos indígenas aceptaban lo nuevo impuesto sólo en la medida en 
que podía ser insertado en su mundo tradicional. En cualquier caso, no fue un proceso pasivo y una relación unidireccional. ${ }^{29}$

Estos resultados significan que los procesos de construcción de memoria siguieron funcionando dentro del marco de la tradición autóctona; si se admite que estos resultados pueden aplicarse a otros contextos culturales, se abre un campo para nuevas lecturas del pasado, no tanto en el sentido de que haya que suponer la existencia de muchos objetos que todavía van a ser descubiertos, sino mas bien en el sentido de que las realidades creadas por el nuevo poder y que fueron transformando las formas de existencia de la población autóctona, hay que leerlas como hechos que a pesar de su aparente transparencia, en realidad ocultan una gran complejidad. Se trata de ir rescatando lo que de posibles "supervivencias" hay en ellos, una categoría que es mucho más productiva que las tradicionales de "mestizaje"o "aculturación".

Esta nueva lectura no implica la búsqueda o la reconstrucción de un pasado idílico como lo planteado en los frescos creados por Luis Alberto Acuña en su casa-museo de Villa de Leyva. No porque se haya tenido más o menos en cuenta la información científica de que se dispone, sino en el sentido de que se trata de una reconstrucción nostálgica con carácter de reconstrucción total, por lo menos en los términos planteados por él. De lo que mas bien se trata es de aceptar lo fragmentario con todo su potencial de portador y creador de memorias e, indirectamente, subvertir la versión oficial de la historia, escrita desde una perspectiva incompleta o quizás reduccionista.

${ }^{29}$ James Lockhart, Los nahuas después de la conquista: siglos XVII y XVIII (México: FCE, 1999). 
Lo anterior puede enlazarse quizás también con unas consideraciones sobre la Constitución de 1991. Hay un acuerdo general en reconocer que se trata de una Constitución muy avanzada, sobre todo por el hecho de consagrar el principio de "multicultaridad", otorgando a las culturas indígenas existentes amplios derechos para ellas y deberes de protección por parte del Estado.

Pero con ello se corre el peligro de identificar lo "indígena" como lo minoritario. Esto es cierto en términos sociológicos y culturales pero no lo es tanto si se plantea desde una perspectiva histórica. La población colombiana en su gran mayoría es descendiente de la población autóctona, es decir, de la que formaba parte de las llamadas "culturas precolombinas". En este sentido, el término "indígena" es siempre problemático porque construye una alteridad radical que lo aparta del concepto más comprensivo de "lo colombiano", y al ser expulsado este pasado se acaba construyendo el de "lo colombiano" fundamentalmente desde "lo español".

Si la presencia del pasado se enfoca desde el concepto de "pervivencia" entendida en el sentido de Warburg, es posible descubrir y explicar ciertos hechos de otra manera. Quizás se trate de aspectos marginales y aislados pero en cualquier caso reclaman una valoración adecuada.

Sólo como ejemplo de lo anterior se presentan aquiídos casos tomados de la realidad reciente. El primero está tomado de lo ocurrido en Sasaima, un pueblo de Cundinamarca, en la provincia del Gualivá (Imagen 4). En torno al 2010 se inició una reorganizacion total de la plaza principal del pueblo considerándose que en ese contexto, entre otras cosas, era necesario dotarla del monumento correspondiente. El resultado final de esa decisión ha sido el de crear un monumento dedicado al cacique local de la zona en la época precolombina. 


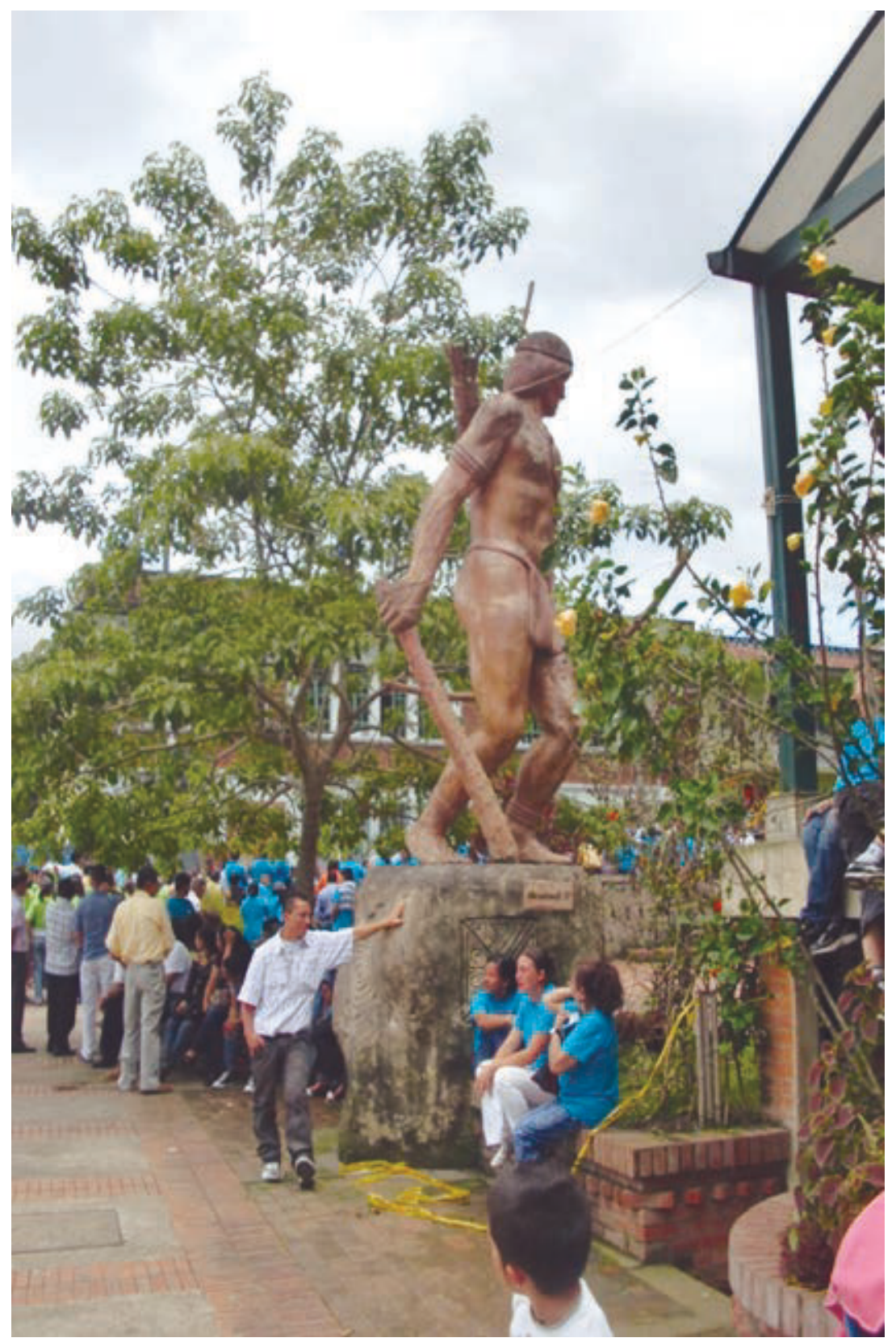

Imagen 4. Monumento al cacique local, Sasaima, Cundinamarca. 
Quizás no tenga esto nada de sorprendente si se tiene en cuenta que esa zona contaba con una densa población indígena antes de la llegada de los españoles. Pero lo mismo ocurría en otros lugares, entre ellos Bogotá, y no se ha producido un fenómeno equivalente. Quiere decir esto que en un proceso de este tipo se ponen en juego muchos elementos.

Es importante señalar que esa decisión ha sido tomada por una población que se consideró a sí misma no como "indígena" sino como"colombiana". Pero a pesar de eso, al parecer, el repertorio de figuras que le aportaba la historia colombiana republicana, no satisfacían la noción de pasado que tiene esa comunidad local. Esto significa que en su autopercepción como colombianos, la realidad precolombina no es algo del pasado sino una realidad a partir de la cual se pueden generar vínculos con el presente. La solución final quizás puede producir desencanto desde una perspectiva purista. Desde ella, se podría considerar que se ha producido un falseamiento importante. La figura que se ha creado para representar al cacique no establece ningún vínculo con la estética de las estatuas conservadas en las colecciones de los museos. Recuerda mas bien a las imágenes de héroes de la cultura popular, tanto en los comics como en el cine, una figura más o menos tipo superman. Probablemente ese era el lenguaje formal del que disponía esa comunidad. Pero un examen más detenido del conjunto creado, muestra una realidad no tan simple. En el pedestal sobre el que se eleva la imagen, en cada una de sus caras, se han reproducido petroglifos existentes en la zona (Imagen 5). 


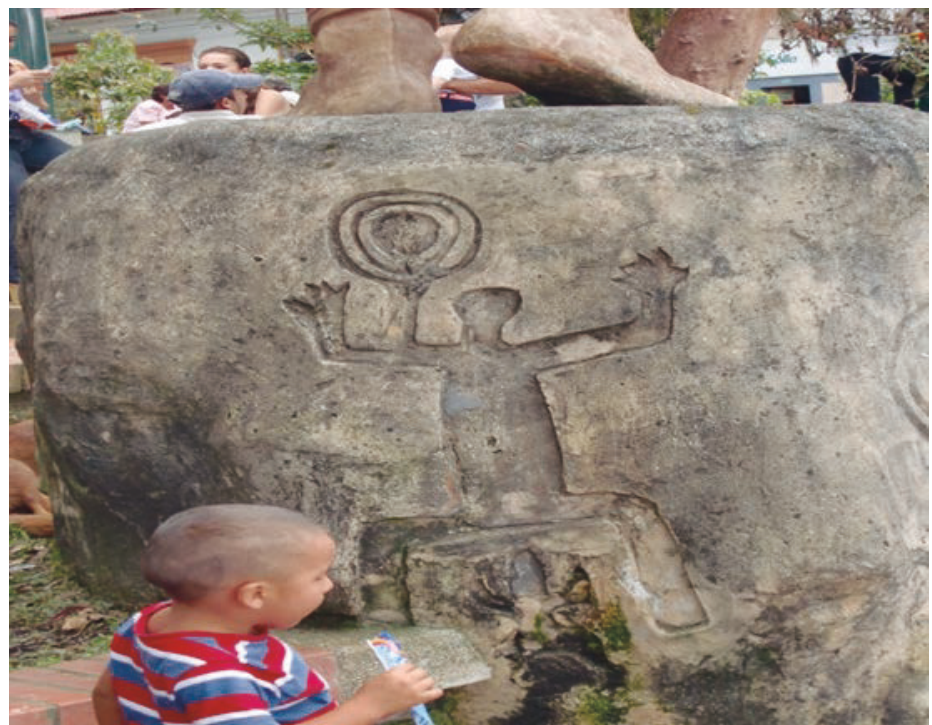

Imagen 5. Monumento del cacique local, Sasaima. Detalle del pedestal con la reproducción de petroglifos de la zona

Además en una inscripción en bronce se ha escrito el nombre de "Sasaima" con su correspondiente traducción al español.

La mejor manera de valorar lo ocurrido en la elaboración del monumento es tratarlo como los efectos de un caso de "supervivencia"; es decir, partiendo de una presencia difusa del pasado, instalada en el recuerdo colectivo de la comunidad se ha generado una nueva presencia, una actualización en forma de un monumento altamente híbrido, pero claro en la intención. Este tipo de fenómenos surgen con dinámicas distintas a las puestas en marcha desde las instituciones oficiales. En este sentido, no se pueden programar, pero es llamativo el dato, de que si uno recorre la zona se puede detectar la frecuencia con la que en diversos lugares los comercios o establecimientos de otros tipos invocan nombres de antepasados locales que no tienen nada que ver con la historia oficial. Sin duda estas observaciones se refieren a fenómenos todavía muy marginales y es difícil encuadrarlos con seguridad en un marco de 
interpretación más general. Pero una categoría como las de la "pervivencia" es suficientemente ductil para rescatar los diversos niveles de lectura posible.

El segundo hecho que se propone parte de una exposición de fotos. En el año de 2012 en la biblioteca Virgilio Barco de Bogotá, se presentó un conjunto de fotos, resultado de un proyecto apoyado por varias ONGs bajo la etiqueta de "Talleres de Cazucá". El objetivo era promover procesos alternativos de reconstrucción de la memoria individual y colectiva. Para ello se había puesto a disposición de niños y jóvenes de algunos barrios periféricos una serie de cámaras fotográficas para que dirigieran su mirada con ellas a su mundo familiar, local $\mathrm{y}$ a su entorno natural en el que viven.

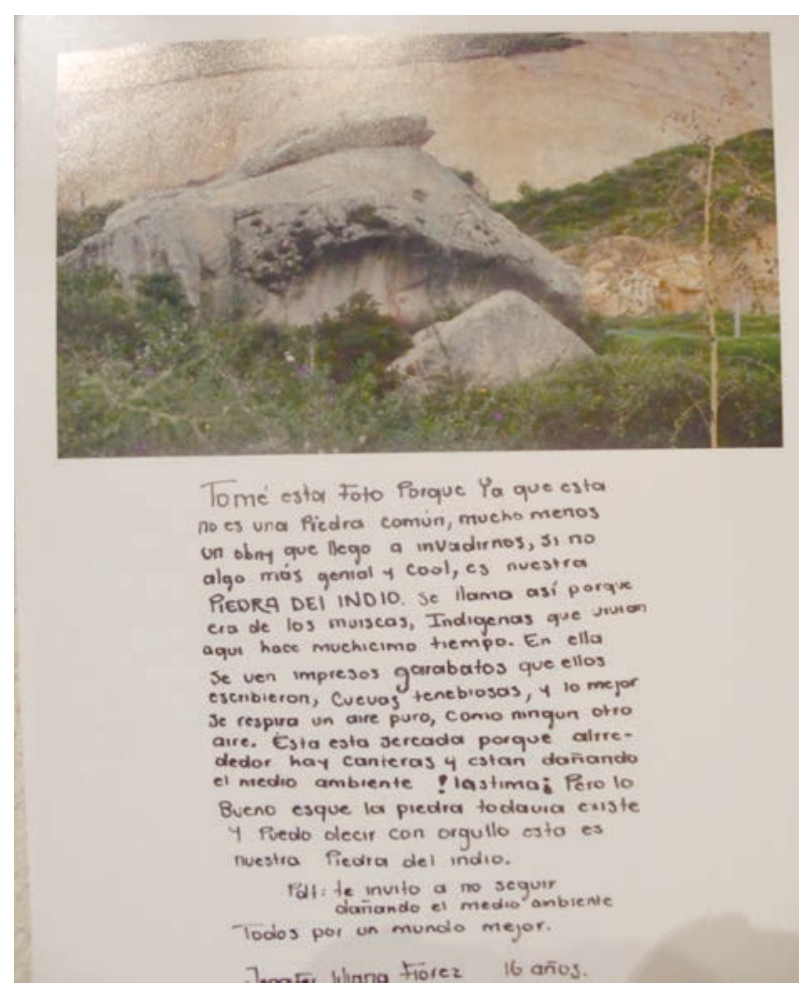

Imagen 6. Foto paisaje "Talleres de Cazucá" 
Las fotos en la exposición iban acompañadas de textos breves, escritos por los mismos autores de las fotos, en los que se comentaban impresiones relacionadas con la realidad fotografiada. En una primera valoración de su lectura, después de haber superado la sensación de verse confrontado con una suma de impresiones muy diversas sin una línea unificante, se iban destilando algunas vías o categorías de percepción de esa realidad. Quizas la más destacada era la sensación de amenaza y destrucción de su paisaje, que ellos percibían como bello, pero en el que constataban la imparable presencia de basuras cada vez más amenazantes.

Otro grupo, bastante menor que el anterior, pero por su contenido menos previsible es más significativo, es el de los que la visión del paisaje les traía pensamientos sobre el pasado de las poblaciones anteriores a los españoles que habían ocupado esos paisajes (Imagen 6). Este resultado es sorprendente puesto que esa rememoración frente a lo que ocurría en el grupo anterior, no se puede anclar en datos físicos de percepción inmediata, por ejemplo, podrían ser la presencia de ruinas. Solo cabe especular cómo se pudo producir ese efecto: se puede sospechar algún comentario en la escuela o en el entorno familiar en ese sentido; en cualquier caso, el material del que partía su mente no era mucho más que frágiles fragmentos, alusiones, indicaciones que podían flotar en su recuerdo y por una vía emotiva derivada del impacto de la belleza del paisaje se generaba una unión, una nueva percepción que reunía presente y pasado.

En una proyección más amplia no es difícil imaginar el potencial de este tipo de experimentos, o mejor experiencias, que se producen a través de miradas espontáneas, apenas controladas por el discurso dominante. Es posible pensar que en contextos densos en 
huellas del pasado como son las regiones de la Sabana, estos procedimientos pueden ser vías interesantes de reconstrucción de "huellas", además teniendo en cuenta que pueden ir flanqueadas por los resultados que aporta el "Archivo", en forma de estudios arqueológicos y antropológicos.

Esto lleva a la otra gran cuestión apuntada anteriormente, la primera de las dos, en las que se condensaba la argumentación, es decir, cuáles son las posibilidades de que el "Archivo", entendido éste como el conjunto de objetos, tanto coleccionados como los conocimientos proporcionados por las investigaciones de las disciplinas correspondientes, se convierta en una herramienta potente para generar memoria colectiva.

No es posible tratar de modo adecuado esta cuestión en el marco del presente ensayo, pues requeriría discutir en detalle la estructura de un museo, estrategias de presentación de objetos, papel de las curadurías, etc.

A título de orientación sólo se propone en consideración dos fenómenos observados en las colecciones del Museo Nacional en Bogotá, insistiendo en su carácter de marginalidad dentro del conjunto de la colección. Con motivo de las celebraciones del segundo aniversario del centenario de la independencia se hizo una reorganización muy importante en la manera de presentar las colecciones. En torno a ello se ha generado una discusión muy intensa sobre si las soluciones adoptadas eran acertadas o no.

Independientemente de la posición que se tome ante ella, hay un aspecto que cabe señalar que ocupaba una cierta centralidad en la elaboración del proyecto. Uno de los ejes en el planteamiento de la propuesta museística 
adoptada era el de la necesidad de que el museo no sólo fuera la colección de la memoria de los grupos dominantes sino que tenía que dar cabida a la memoria de los diferentes grupos de la sociedad en general. Es posible que esta exigencia en lo que respecta al planteamiento museístico no sea fácil de resolver y que probablemente sobrepase las posibilidades discursivas que permiten el tipo de objetos reunidos en la colección del Museo Nacional. Sin embargo, la exigencia sigue teniendo validez, y sería un retroceso que como consecuencia de las críticas se dejara de tener en cuenta.

Los dos fenómenos aquí descritos se destacan por el grado de ruptura frente a los procedimientos normales de presentación y de alguna manera -como se indicará luego- se enlazan directamente con algunas de las ideas de Aby Warburg expuestas anteriormente. La primera se refiere al espacio ocupado por la sección de historia virreinal (Imagen 7 ).

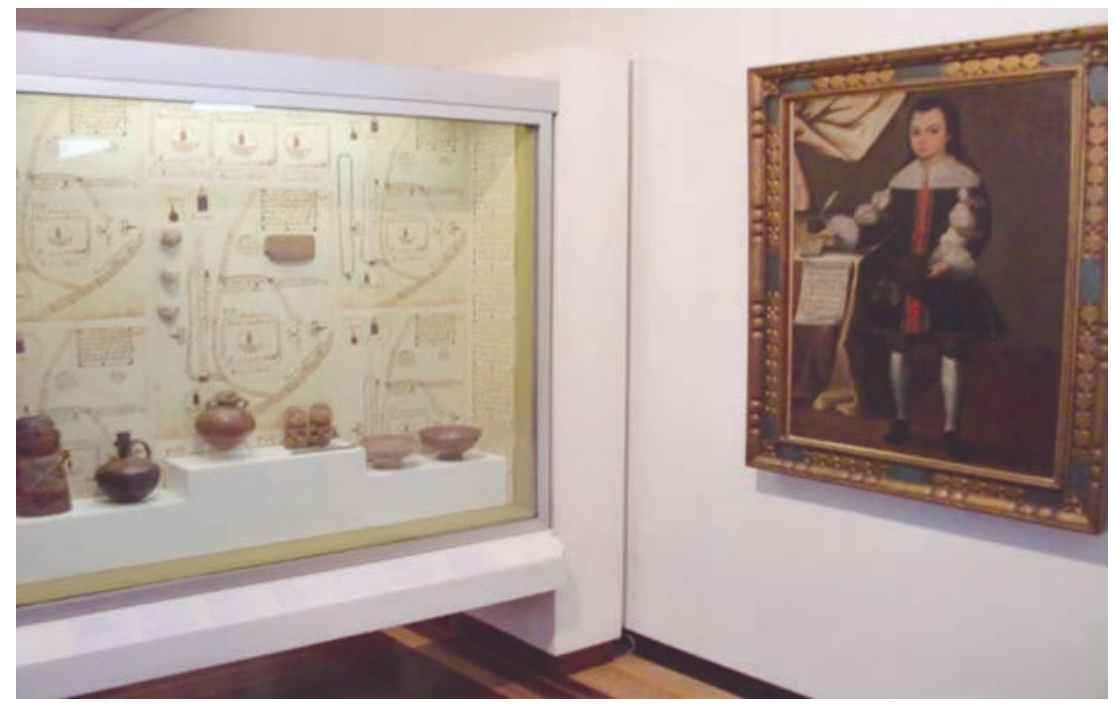

Imagen 7. Vitrina de la coleccion de Arte Virreinal, Museo Nacional de Colombia, Bogotá 
En él había unas vitrinas que estaban en la parte destinada a informar la distinta composición racial de la sociedad de entonces: la dedicada a la población negra. En ellas además de proporcionar una serie de datos sobre tal grupo de población, se exponían una serie de artefactos culturales de ese conjunto étnico. Esto provocaba una irritación especial en el espectador porque su mirada está acostumbrada a ver estos objetos sólo, o de modo preferente, en colecciones de arte etnográfico. De pronto, el mero hecho de agruparlas en esa sala en un contexto completamente distinto, es decir, dentro de un discurso de "historia nacional, "provocaba otra mirada, con lo cual esos objetos adquirían una serie de significaciones inesperadas.

El segundo caso, procede de la sección destinada al período de la conquista (Imagen 8). En una vitrina muy escueta se mostraban tres imágenes del mundo religioso de los tres grupos de población que integraban esa sociedad: el de los conquistadores, el de la población indígena y el de la población negra. Sin duda, desde un punto de vista etnográfico, esta clasificación es muy simplificadora. Pero el objetivo de la vitrina era más bien mostrar que había diversas tradiciones religiosas con su mundo respectivo de imágenes. Las tres imágenes expuestas eran de tamaños parecidos y estaban colocadas una al lado de otra en pie de total igualdad, lo mismo las cartelas que las identificaban, las tres tenían la misma información básica. La que representaba la religión de los conquistadores era un crucifijo, pero allí se identificaba simplemente como imagen religiosa de la población europea. Esta estrategia expositiva, independientemente de su intención, conseguía de nuevo una serie de efectos desestabilizadores que se movían en varias direcciones. En primer lugar, la extrañeza de colocar las tres imágenes en pie de igualdad, con lo cual 
el crucifijo quedaba despojado de su carácter de imagen hegemónica en el mundo religioso.

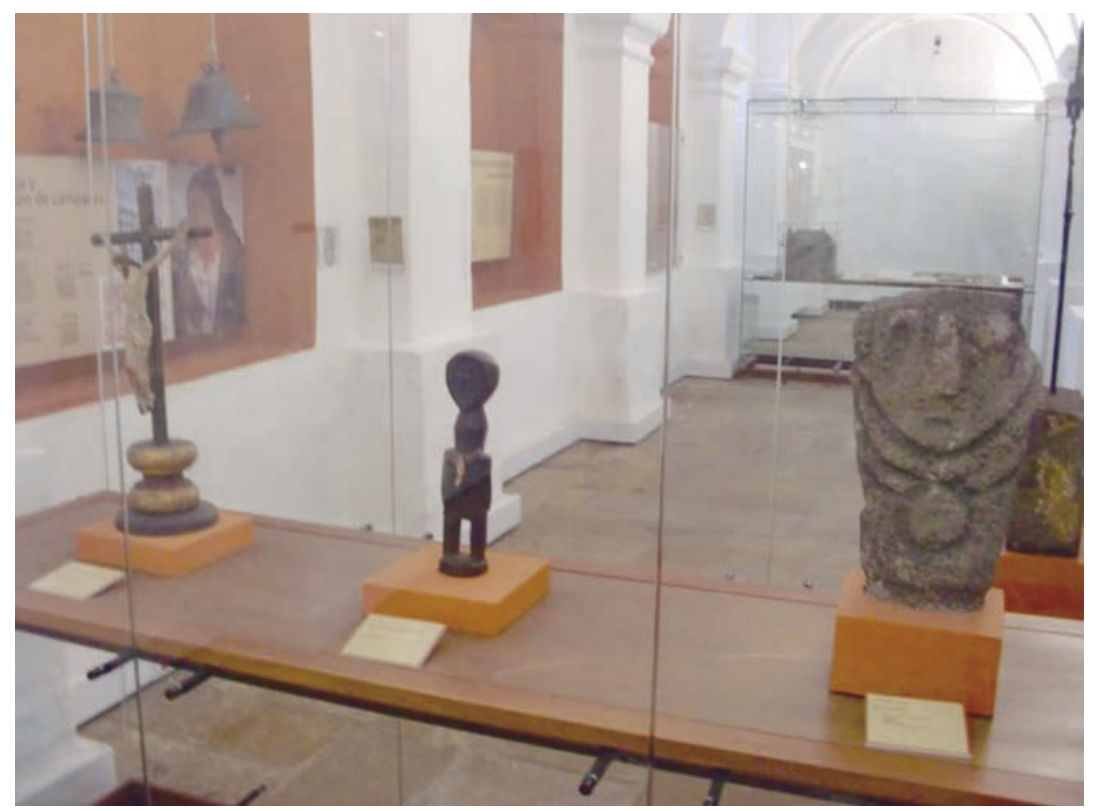

Imagen 8. Vitrina de la colección época de la Conquista, Museo Nacional de Colombia, Bogotá.

El segundo efecto, era que el crucifijo se percibía como una imagen nueva con toda su extrañeza. Luego venían los procesos de comparación derivados de las diferencias en las tres imágenes. Cada mirada comparativa iba creando nuevos sentidos en cada una de ellas, provocados por el simple hecho de la comparación. Y este proceso adquiría un carácter de apertura creciente, pues la comparación se podía extender del conjunto de la imagen o a la comparación de elementos parciales en cada una de ellas, y así sucesivamente.

No es dificil percibir que lo que proponía esta vitrina, sin probablemente proponérselo, era un dispositivo muy parecido a los que propone Aby Warburg en las tablas de su Atlas Mnemosyne. Experiencias de este tipo pueden 
ser muy determinantes en el sentido de que liberan a las imágenes y dejan que su energía actúe con su capacidad de crear nuevos procesos de memoria. Sería una forma de revitalizar el legado recogido en los museos y conectarse con la fuerza y la energía acumulada, en ese pasado no negado pero tampoco suficientemente integrado.

\section{Conclusiones}

Los procesos de construcción de memoria no pueden imponerse, pues la memoria es algo vinculado con la realidad, la necesidad o la emotividad de una colectividad. Pero las imágenes del mundo precolombino obedecen a unas necesidades de tipo religioso emocional, equivalentes a las que se producen en la época colonial. En este sentido, a pesar de sus diferencias formales o estilísticas se las puede poner en diálogo, crear dispositivos como los del Atlas Mnemosyne de Warburg para que generen nuevos sentidos. La idea de pervivencia de Warburg se puede tomar con toda su fuerza y explotar su potencial, tal como ofrecen el caso de Sasaima o los "Talleres de Cazuca", cuya pervivencia se acerca al concepto de "presencia fantasmal", pero no menos real y efectiva que la del caso anterior. Con ello se está por lo menos también planteando la cuestión de si los contextos museísticos habituales son el marco más adecuado para lograr estos fines. El hecho de estar conservadas en un museo las salva de su destrucción u olvido, que no es poco, pero las limita en el despliegue de su potencialidad, o, en términos de Warburg, que transmitan la "energía" contenida. La mirada etnográfica o arqueológica en la mayor parte de los casos es más rígida. Por ello hay que pensar en otros contextos de presentación. 
Las ideas de Warburg son a veces escurridizas pero abren nuevas vías de abordar las imágenes. Sus propuestas pueden ser ampliadas o completadas con otras no menos sugerentes como las originadas en torno a Bataille, el historiador de arte Einstein y la revista Documents también por esas fechas. En ellas, se proponían lecturas todavía muy innovadoras de las imágenes de otras culturas, en especial las africanas..$^{30}$ Esto se realizaba desde París en una realidad alejada de los contextos de esas culturas.

La diferencia de iniciar esos procesos desde París o desde el propio contexto es importante, pues desde allí se partía fundamentalmente de categorías estéticas. En cambio, una mirada sobre el propio pasado cuenta con el apoyo del saber acumulado desde la arqueología y antropología propia, lo que le da a todo el proyecto más densidad. Cabe, sin embargo, pensar también en estrategias modestas ajustadas a las posibilidades de contextos circunscritos a ámbitos culturales bien delimitados. Por ejemplo situaciones pensadas desde a Sabana con su fuerte legado Chibcha.

Las estrategias pueden ser múltiples, desde movilizar la toponimia, un patrimonio poco explotado, observar las continuidades en el manejo del campo y del agua, estudios astronómicos, o bien, crear nuevos contextos para las exposiciones de los objetos y figuras de los museos.

Una mirada atenta a los rostros de las figuras de la colección del Museo Nacional transmite una inmensidad

\footnotetext{
30 Documents revista creada por un grupo surrealista en torno a Georges Bataille, que se había distanciado de la línea de André Breton. Se publicaron 15 números entre abril de 1929 a enero de 1931. La biblioteca Nacional de París la ha hecho accesible digitalmente.
} 
capaz de romper el caparazón del tiempo y conectar directamente en lo que tienen de humanidad con los sentimientos de la sociedad actual.

\section{Bibliografía}

Derrida, Jacques. Spectres de Marx, París 1993.

Didi-Huberman, Georg. L'image surivivante, histoire de l'art et temps de fantomes selon Aby Warburg“. París: Ed. Minuit, 2002.

Didi-Huberman, Georg. Atlas ¿Cómo llevar el mundo a cuestas? Madrid: MNCARS, 2011.

Dresler, Martin. Kunst und Neurowissenschaft en Neuroästhetik: Kunst, Gehirn und Wissenschaft". Leipzig: Ed. Dresler Martin, 2009.

Halbwachs, Maurice. Les cadres sociaux de la mémoire. París, 2009.

Halbwachs, Maurice. La mémoire collective. París, 1939.

Keilson, Hans. Festschrift Geschichte als Trauma. Frankfurt, 1991.

Kongress Tel-Aviv. Holocaust und Trauma. Ed. Göttingen, 2011.

Múnera Ruiz, Leopoldo. La regeneración revisitada: pluriverso y hegemonía en la construcción del estad-nación en Colombia. Bogotá: La Carreta, 2011.

Nora, Pierre. Lieus de Mémoire 7 vols. (París, 1986-1992)

Pérez Benavides, Amada Carolina. "Las representaciones de la nación en América Latina, siglos XIX y XX", Memoria y Sociedad No. 28 (enero-junio 2010): 85-106. 
Reichel-Dolmatoff, Gerardo. Beyond the milky way. California: Ucla,L.A, 1978.

Reichel-Dolmatoff, Gerardo. Goldwork and shamanism. Colina, 1988.

Richard, Nelly. Antología de la Revista de Crítica Cultural. Chile, Ed. Arcis, 2009.

Rincón, Carlos. Consideraciones morales sobre el Museo del Oro del Banco de la República, (en prensa).

Warburg, Aby. Sandro Botticelli. Madrid: Casimiro Libros, 2010 .

Warburg, Aby. Werke in einem Band auf der Grundlage der Manuskripte und Handexemplarea. Berlin: Ed. Suhrkamp, 2010.

Warburg, Aby. Atlas Mnemosyne. Madrid: Ed. Tres Cantos, 2010 .

Weigel, Sigrid. "Die Kunst de Gedächtnisses ,das Gedächtnis der Kunst, zwischen Archiv und Bilderatlas" en Flach Sabine Bilderatlas im Wandel der Künste und der Medien. München, 2005. 